\title{
Lecturas constitucionales gaditanas
}

\section{Cadiz constitutional readings}

\author{
Faustino MARTÍNEZ MARTÍNEZ \\ Profesor Titular de Historia del Derecho \\ Departamento de Historia del Derecho \\ Instituto de Metodología e Historia de la Ciencia Jurídica \\ Facultad de Derecho. Universidad Complutense de Madrid \\ fmartine@der.ucm.es
}

Aceptado: 8 de marzo de 2013

Recibido: 31 de mayo de 2013

\section{RESUMEN}

Se presentan aquí diversas lecturas interpretativas coetáneas a la Constitución de 1812, orientadas a poner de manifiesto su afrancesamiento, su carácter marcadamente religioso y, sobre todo, su dimensión historicista como recuperación de las viejas Leyes Fundamentales de la Monarquía.

PALABRAS CLAVE: Ilustración, Constitución de Cádiz, constitucionalismo, Historia Constitucional de España, interpretación.

\begin{abstract}
Various interpretive readings coeval with the Constitution of 1812 are presented here. They are aimed at highlighting its Frenchness, its distinctly religious character, and above all, its historicist dimension, as a recovery of the old fundamental laws of the monarchy .
\end{abstract}

KEYWORDS: Enlightment, Cadiz Constitution, Constitutionalism, Constitutional History of Spain, Interpretation.

\section{RÉSUMÉ}

Diverses interprétations des lectures contemporaines de la Constitution de 1812 sont presentées ici, visant à mettre en évidence sa francité, son caractère nettement religieux, et surtout, sa dimension historiciste comme une reprise des anciennes lois fondamentales de la monarchie.

MOTS CLÉ : Lumières, Constitution de Cadix, Constitutionnalisme, Histoire constitutionnelle de l'Espagne, Interprétation.

\section{ZUSAMMENFASSUNG}

Es werden hier gleichzeitig entstandene, verschieden zu interpretierende Lesarten der Verfassung von 1812 vorgestellt: einmal orientiert an der Ausprägung der Frankophilie, dem religiösen Charakter und, vor allem, der historischen Dimension hinsichtlich des Wiederaufgreifens der alten Gesetze der Monarchie.

SCHLÜSSELWÖRTER: Aufklärung, Verfassung von Cádiz, Konstitutionalismus, Verfassungsgeschichte Spaniens, Interpretation/Lesart. 
El Derecho, como nos ha enseñado Gregorio Robles, no es más que un conjunto de textos de intensidad obligatoria variable ${ }^{1}$. Frente a diversas concepciones anteriores en el tiempo, de todos conocidas, que ponían el acento en el marco ético, moral, coactivo o simplemente fáctico de todo orden jurídico, la solución más sencilla en estas lides o prolegómenos pasa por preguntarse no tanto qué es el Derecho, cuestión que puede devenir irresoluble e inalcanzable, sino cómo es el Derecho. Y así, tras esa pregunta forzada y claudicante que, al mismo tiempo, renuncia a sustancias, a ontologías, y se concentra en rasgos externos, fenomenológicos si se quiere, surge la respuesta tranquila y plácida: el Derecho es, por encima de todas las cosas, texto, pero un texto especial y cualificado por las implicaciones que del mismo se derivan en orden a la realización de aquellos mandatos que en él se contienen. Aceptada esta primera afirmación capital, se sigue de la misma que una de las tareas esenciales del jurista acaso la tarea por excelencia- es precisamente hacer hablar a esos textos, es decir, interpretarlos, operación que tiene que entenderse como el proceso conducente a la aplicación de ese Derecho a la realidad que debe regular, precedida por la anticipada comprensión del mismo como presupuesto para efectuar lo anterior. Son textos, pero inicialmente son textos mudos a los que hay que hacer expresarse con el fin de dialogar con ellos. La interpretación es el camino para que ese lenguaje se exteriorice: como adaptación exige, en primer lugar, la lectura y la comprensión de la norma o, más exactamente, de la proposición normativa llamada a convertirse en norma jurídica, a modo de embrión de la misma. Y para que todo esto pueda llevarse a la práctica se debe tener en cuenta no sólo el texto normativo del que se trate (las palabras) o el pretexto que ha conducido a una formulación normativa concreta, la cual ha determinado una opción en lugar de otra, es decir, que ha justificado el pronunciamiento del legislador o del hacedor de leyes en uno u otro sentido (la explicación).

Conocer el Derecho, ahora o en un periodo histórico anterior, exige avanzar un poco más, ir más allá de letras y palabras, de explicaciones y de argumentos, y buscar el envoltorio que aglutina todos estos elementos citados: el texto, el pretexto y, finalmente, el contexto, es decir, aquella cultura en la que nacen, crecen y se desarrollan los instrumentos intelectuales que sirven para formular e interpretar el Derecho estudiado, y que explican la propia conformación de ese orden jurídico determinado. Esta cultura jurídica, esta civilización del Derecho que está en su base y que lo hace legible y comprensible por y para sus coetáneos, conforma el marco dentro del cual viven, debaten y discuten los juristas y así, por medio de esta pugna, forjan su lenguaje, sus conceptos, sus categorías, sus principios y sus valores. Es el cemento que acaba por unir todos los mecanismos citados: el que liga las palabras de la norma, las justificaciones de la misma y sus explicaciones finales y últimas. Se trata de la reserva inte-

${ }^{1}$ Vid. G. Robles Morchón, El Derecho como texto (Cuatro estudios de Teoría comunicacional del Derecho), Madrid, 1998. 
lectual que infunde existencia al orden jurídico en su conjunto y que lo sostiene contra viento y marea, como paso previo para su formulación, al mismo tiempo que se convierte en el parámetro indispensable para la posterior comprensión del Derecho formulado. El contexto cultural explica, pues, el Derecho, su lectura y su entendimiento por parte de todo lector que se acerque al mismo. Si no conseguimos aprehenderla, si no captamos esa atmósfera que envuelve al orden jurídico casi de modo imperceptible, no tendremos todos los mecanismos para conocer ese Derecho de forma global en un determinado período histórico y nuestra aproximación al mismo será siempre parcial, fragmentaria, incompleta, insuficiente. El texto, pues, como norma con los efectos plenos que indefectiblemente comporta, hace lo que le es propio: expone, manda, ordena, prohíbe, permite, tolera, anula o convalida; el pretexto, de donde procede el testimonio anteriormente indicado, ese texto mismo, lo trata de explicar en toda su profundidad e intensidad; y el contexto, en el que se incardinan los dos previos elementos, justifica o legitima todas las operaciones anteriores, puesto que dota de sentido a la coercibilidad, a la imperatividad y a la previa, simultánea o sucesiva apoyatura de las mismas. Con estos tres elementos entrelazados e interdependientes, con estos tres instrumentos culturales (pero no sólo), se puede intentar la comprensión del Derecho actual. Y también del pretérito como es nuestro propósito en las líneas que siguen.

Una de las implicaciones derivadas de la aceptación de todo lo anterior radica en el modo y manera en que el Derecho debe ser leído desde una perspectiva histórica. Aquí surgen dos posturas enfrentadas que prácticamente nos hacen cuestionar la labor misma del historiador jurista y de los enfoques que deben presidir ésta. ¿Qué visión del orden jurídico debe predominar? ¿Qué lectura es la más aceptable? ¿Cómo se debe leer y comprender el Derecho del pasado? ¿Qué debe hacer el historiador del Derecho con ese Derecho que es Historia, que ya no está en vigor, que carece de obligatoriedad y de coactividad, aunque las tuviera in illo tempore? Dos posibilidades se abren ante nuestros ojos: o bien una lectura conforme a los patrones del momento en que tal Derecho fue creado, o bien una lectura conforme a nuestros patrones contemporáneos, sobreentendiendo que, en ambos casos, el historiador se verá obligado siempre a emplear un lenguaje presente, lo que constituye ya de por sí un cierto riesgo de anacronismo que debemos y podemos asumir sin mayores complicaciones. Todo historiador habla del pasado en un lenguaje actual. Lo que no puede hacer el historiador es trasladar al pasado el caudal conceptual que lleva consigo, es decir, su cosmovisión, su universo intelectual, su repertorio de ideas, y tampoco puede trasponer al presente la rémora pretérita sobre la cual trabaja. Cada momento histórico, cada texto que es testimonio de éste, debe ser leído, glosado e interpretado a la luz del universo mental en el que se forja y nunca por medio de otros cauces o parámetros, por medio de otras derivaciones. El Derecho debe captarse de acuerdo con la mentalidad de la época en que fue creado, como vacuna que neutraliza el juego combinado de los dos anacronismos implicados. Ni del pasado se puede ir hacia el presente, ni del 
presente hacia el pasado. Cada norma histórica debe ser interpretada exacta y estrictamente de conformidad con el mundo conceptual en el que aquélla ha surgido, con arreglo a su tiempo y lugar. Nada más y nada menos que esto parece ser el propósito que guía a un honesto historiador del Derecho que se precie de respetar las fuentes y el contexto en que éstas aparecen.

Acaso la cuestión capital del constitucionalismo gaditano radique en el valor mismo que como Constitución presenta el texto aprobado el 19 de marzo de 1812 en el Oratorio de San Felipe Neri y la percepción que acerca de él tuvieron quienes lo elaboraron ${ }^{2}$. Es evidente que Cádiz no puede ser reputada como una Constitución moderna, en sentido racional-normativo, toda vez que el poder constituyente, que debía articularla, brilla por su ausencia y no comparece ni por asomo como consecuencia de la imposibilidad subyacente de fundar una Nación liberal, de ciudadanos políticamente activos, y de maximizar a través de ésta una soberanía que no acaba de encajarse exclusivamente en dicha colectividad, sino que se muestra dispuesta a compartir sus facultades y marcas con la Monarquía que estaba en la base de todo y, a través de ella, con el completo universo plural de corporaciones, territorios y jurisdicciones que conformaban ese cuerpo complejo que presidía Su Católica Majestad de las Españas. No olvidemos que era ese texto una Constitución política pensada no para una Nación española, sino para una Monarquía así llamada, lo que muestra de forma meridiana la respuesta a la pregunta de quién es el que manda que debe encabezar cualquier reflexión sobre el particular mundo constitucional gaditano. Era una Monarquía que llamaba a la Nación para ayudarle en su recomposición y eso transformaba a esa Nación en un cuerpo eminentemente monárquico. Esta imposibilidad provocó la incapacidad de esa Nación misma para romper con la Historia de donde se traía causa y donde se fundaba el orden político en su conjunto, a modo de última instancia depositaria de unas esencias imperturbables. La Constitución de Cádiz procedía a una reordenación de las viejas Leyes Fundamentales, con método y sentido nuevos, complementadas por toda una gama de providencias y provisiones destinadas a asegurar su cumplimiento y su recuerdo de cara al futuro más inmediato, lo cual, de todo punto, impedía la aparición de un poder constituyente, concebido como aquel poder llamado a expresar de forma libre e irrestricta la voluntad política de la Nación. Nada de eso hubo en Cádiz: se recompuso la Monarquía por medio de la Nación para mayor gloria de ambas, pero no se hizo, porque no se pudo hacer, una Constitución

\footnotetext{
${ }^{2}$ Síntesis bibliográfica sobre el mismo en F. Martínez Pérez, "La Constitución de Cádiz de 1812 y sus consecuencias", Índice Histórico Español, n 125, 2012, pp. 157-185, reproducido asimismo en Anthropos. Cuadernos de Cultura Crítica y Conocimiento, $\mathrm{n}^{\circ} 239$ (La Constitución de 1812. El nacimiento de la libertad. Número coordinado por Manuel Aragón y Juan José Solozábal), bajo el título "Balance bibliográfico del Bicentenario de la Constitución de 1812”, pp. 183-195. Valoración crítica de la misma bibliografía en B. Clavero, "Cádiz 1812: antropología e historiografía del individuo como sujeto de Constitución”, Quaderni Fiorentini per la Storia del Pensiero Giuridico Moderno, n 42, 2013, pp. 201279.
} 
rotundamente nueva y de espaldas a la Historia. Como he tenido oportunidad de escribir, la Constitución aprobada el 19 de marzo de 1812, luego difundida, recibida y jurada en todos los territorios de la Monarquía Hispánica, es algo que difícilmente puede ser reputado como un texto auténticamente constitucional, bajo prisma moderno, en el sentido de ver en aquélla una norma escrita sólidamente racionalizada, fundada en una serie de valores procedentes de la naturaleza y formulados por medios racionales, valores abstractos que conformaban verdades evidentes por sí mismas, fruto real, efectivo e indiscutible de un poder constituyente que obrase como tal, con la más absoluta de las libertades a la hora de establecer un orden político que respondiera a las únicas orientaciones, expectativas y deseos de la Nación soberana que se hallaba en su base, es decir, sin coacciones, ni condicionantes o imposiciones de ninguna clase, ni regios, ni históricos, ni religiosos, ni tampoco derivados de la tradición. No es así una Constitución moderna, si por tal entendemos una Constitución racional y normativa, fruto puro de la razón abstracta y con fuerza vinculante absoluta, derivada de la máxima expresión volitiva del sujeto que quiere crearla y que quiere darse, a través de ella, un orden político nuevo, libre, global, completo, sin ataduras. Frente a la Nación, recién aparecida y libre, y a la Razón constitucionalizada, arquitecta del sistema en su conjunto y con amplias cotas de novedad, tal y como enseñaban los modelos revolucionarios liberales francés y norteamericano, Cádiz opone Historia y Dios como poderosos y exclusivos factores constituyentes, derivados de un duro y rocoso caparazón católico que impedía difusiones más allá de sus fronteras, pero, al mismo tiempo, evitaba contaminaciones externas. Esto es: frente a un constituyente avant la lettre, se erige una Historia que lo es, constituyente, por encima de todas las cosas y una Divinidad que reclama para sí ese atributo por su carácter indiscutiblemente necesario, nunca contingente. Esto va a marcar el destino y las lecturas que se harán de la Constitución aludida ${ }^{3}$.

Toda época histórica procura su eternidad y ese momento hispánico convulso, del que Cádiz constituyó una suerte de compendio final, no fue excepción, mediatizado por una falsa apariencia de transición en lo que era, a todas luces, un proceso claro de introspección. Se buscaba trasplantar más allá de los límites lógicos de vitalidad el legado de la Ilustración. Fue esa propuesta constitucional, pues, el último intento desesperado por condensar el credo político del Antiguo Régimen, que no del absolutismo, a modo de tabla de salvación de un mundo que se iba, con el propósito de hacerlo (sobre) vivir unos años más camuflado o disfrazado, ante el inminente desplome de todo lo conocido hasta ese instante como se había puesto de manifiesto en las plurales crisis que vivía la Monarquía a comienzos del siglo XIX. La solución fue mantener todo aquello que podía ser conservado (cuanto más, mejor), todo aquello

\footnotetext{
${ }^{3}$ Remito a mi trabajo, "Repensar la Constitución de 1812: Cádiz o el imposible constituyente", Historia et Ius. Rivista di Storia Giuridica dell'Età Medievale e Moderna, no 3, giugno, 2013. Paper nº 6, pp. 1118 [www.historiaetius.eu], con la bibliografía allí citada.
} 
que era considerado esencial para definir jurídica y políticamente a España, tal y como lo pretérito lo acreditaba y lo probaba con numerosos ejemplos. Cádiz fue la respuesta en clave constitucional, la solución constitucionalizada, a un momento crítico único, extraordinario e irrepetible, en el que parecía que todo, sin excepción, se iba a desmoronar dejando huérfanos de poder, de instituciones, de atención, de tutela, de deberes y de derechos, a todos los súbditos de los muy católicos reyes de las Españas. Para tratar de amarrar a buen puerto esa Monarquía a la deriva, se echó mano del pasado como firme pilar al que sujetar un espacio político e institucional que se descoyuntaba por todas partes y se le dio además por vez primera la forma escrita de una Constitución. La antigua Verfassung, dispersa, ignorada, irreconocible, oculta, pasó a ser Konstitution, cuando menos, formalmente bajo aspecto escrito. Ante la crisis, la respuesta fue más y mejor pasado, matizado, recuperado y reordenado, bajo la forma de herencias y reformas antes que de esperanzas de futuro, de alteraciones y de revoluciones que a nada bueno podían conducir. Compendiaron así cúmulos de contrastadas experiencias y de hechos ya sucedidos, por ende, susceptibles de valoración positiva y de ser repetidos y reiterados hasta el infinito, siempre, experiencias y hechos de acrisolada efectividad. Se acogieron a lo acontecido, a lo que ya había funcionado y se suponía que iba a seguir funcionando con pequeños ajustes, antes que decidirse por preludiar promesas, esperanzas, ilusiones y futuros, ya perfectos, ya imperfectos. Prefirieron los definidos y marcados espacios de las experiencias, claras, amplias, exitosas y fructíferas, antes que los difusos e ignotos horizontes de las expectativas, ocultas e imprevisibles, conceptos opuestos, radicalmente antitéticos, en donde está compendiada la ruptura constitucional moderna, la cual supone abandonar lo primero (el pasado) para intentar lo segundo (el futuro) por medio del instante de ruptura que implica la misma Constitución. Mucha tradición y algunas dosis de modernidad, sin excesivas concesiones y dentro de un orden contenido.

De acuerdo a este planteamiento expresado, Cádiz ha de leerse y comprenderse, pues, desde el siglo XVIII, como recuperación, renovación y condensación de esa centuria que se tiene el deber de salvar en modo imperativo, porque es este siglo en el que piensan, se educan, se forman, debaten, discuten y escriben los hombres que redactan todos y cada uno de sus preceptos. En consecuencia, quieren hacer perdurar el mundo que han conocido y de cuyos fundamentos se han empapado, no porque fuese el único percibido (que también sucedía así), sino porque creían a ciencia cierta que era el mejor de todos los conocidos e imaginables. La Constitución de 1812 es obra de los ilustrados hispánicos antes que de unos pensadores liberales en sentido estricto, parangonables a los europeos de su tiempo, por lo que ha de ser analizada teniendo en cuenta el caudal ideológico del que aquellos estaban imbuidos y el lenguaje que aquellos hablaban. No se olvide que eran católicos, más o menos devotos, homogéneos y entregados, y ese catolicismo marcaba el destino de sus reflexiones en conceptos centrales como el de la libertad misma, la soberanía, el poder o la forma de gobierno. Cádiz ha de enfrentarse, por ende, de una vez por todas, a una lectura 
que se efectúe con y desde el conjunto de tópicos del siglo XVIII y de su cultura constitucional, que acaban por depositarse en su articulado, y no someterse a esta lectura parcial, interesada y, en suma, distorsionadora con la que nos obsequiaron los liberales a lo largo del siglo XIX y que ha marcado su destino histórico y, por extensión, historiográfico. Una lectura que ha traído como consecuencia perturbar la comprensión de la Monarquía previamente existente y concebir el mundo jurídico gaditano como una suerte de fundación adánica de todo. Es una obra de sedimentación histórica, de condensación de legados y de tiempos, antes que de fundamentación política de un orden nuevo, de construcción de un novedoso mundo para la posteridad. La Constitución de Cádiz es, antes que nada, regeneración del caos de soberanía, del colapso político y del bloqueo constitucional en que estaba sumida la Monarquía: renovación y convalidación de un orden jurídico tradicional y no fruto de voluntad política alguna, pugna en la que están embarcadas no tanto la Historia y la Política, como realidades diferentes y contrapuestas, con arreglo a las cuales diseñar la cosa pública, una ligada al Antiguo Régimen y a la tradición, la otra vinculada a la revolución y al puro decisionismo, sino el resultado combinado de varias razones históricas que querían imponerse, el efecto de plurales lecturas acerca de la Historia para construir un mundo político remozado. No había contraposición entre tales instancias, sino que la Historia era el único camino para llegar a la Política en el mundo hispánico y configurar de esta manera una que fuese propia, ajena a la europea. Y esto era así porque la vida española del siglo XVIII y de comienzos del XIX había manifestado una total incapacidad para configurar un espíritu moderno y laico que protagonizase la creación de una vida pública en sentido plenamente liberal, con espacios de debate y de diálogo, con mediaciones e intermediaciones, con contratos, pactos y acuerdos, con instituciones que cumpliesen ese cometido de alojar, tutelar o alumbrar consensos y negociaciones (era, pues, algo premoderno y prepolítico). Por fin, lo único que existía, lo único que había quedado en pie de todo el edificio monárquico, era su pasado recreado y recuperado por vías históricas. Todos los sujetos implicados lo sabían y todos los sujetos implicados hablaron, pues, el mismo lenguaje, el lenguaje de las diversas razones históricas, que no era otra cosa que hacer Política a partir de la Historia (nunca al revés), eludiendo la forma pura moderna, respetando el conocimiento histórico y sin pretender nunca superarlo, ni revocarlo, sino actualizarlo de conformidad con los tiempos que tocaban vivir ${ }^{4}$.

La clave esencial estriba en la perspectiva con la que se debe examinar el complejo material forjado entre 1810 y 1812 , ese mundo del ayer que se evaporaba ante los ojos de los contemporáneos, quienes decidieron unir fuerzas para pactar una suerte

\footnotetext{
${ }^{4}$ Para la "historiografía crítica" de los tiempos gaditanos que propugna un acercamiento a estos materiales en el sentido indicado, vid., entre otros, C. Garriga - M. Lorente, Cádiz, 1812. La Constitución jurisdiccional. Epílogo de Bartolomé Clavero, Madrid, 2007; C. Garriga (coord.), Historia y Constitución. Trayectos del constitucionalismo hispánico, México, 2010; y M. Lorente - J M. Portillo (dirs.), El momento gaditano. La Constitución en el orbe hispánico (1808-1826), Madrid, 2012.
} 
de disolución ordenada y paulatina de lo pretérito, una continuidad agotada, y así crear, idear o imaginar otro universo. Para todo ello, emplearon y ensamblaron muchas piezas, materiales, instrumentos y elementos tomados de ese mismo ayer que se estaba precipitando hacia su desaparición, es decir, que procedieron a construir un cosmos en apariencia nuevo a partir de los residuos, restos y reminiscencias que quedaban del antiguo, del único que conocían en profundidad, dando como producto algo que no puede ser calificado, en puridad, como una cosa, ni tampoco como la otra. Cádiz es un mundo exótico que se muestra ante nosotros como algo remoto, lejano, extraño: aparece un ser sin tiempo que tendría muchas dificultades para adscribirse a una era, la que se cerraba, o a otra, la que comenzaba a abrirse. El mundo gaditano gira en torno a esta singular dualidad de planos temporales que se acercan, se tocan, se distorsionan, y, en cierta medida, también se confunden. Pasado y presente se dan la mano porque el horizonte constitucional fue construido sin marcar cesuras con el tiempo más inmediato o más remoto, sin cancelación alguna de ese pasado, sin ruptura o fractura con el mismo (lo acredita la inexistencia de cláusula derogatoria alguna en el texto doceañista), sino trabando un fructífero diálogo con aquél, invitándolo a incorporarse a la experiencia constitucional que, con nueva forma, método y sistema, comenzaba a caminar en septiembre de 1810. Toda la obra legislativa de Cádiz debe ser contemplada desde este prisma: pasado y presente imbricados, entroncados, fundidos, o confundidos, dando pie a una relación abierta y natural, cotidiana si se quiere, entre el hoy y el ayer, entre 1812 y los tiempos góticos, medievales, modernos o los inmediatamente anteriores del despotismo regio y, sobre todo, ministerial, sin que nadie se rasgase las vestiduras, ni se asustase ante tamaña actuación porque la continuidad histórica estaba garantizada: el Derecho del pasado seguía siendo Derecho del presente. Las bases eran las mismas. Eso era lo usual. El ayer todavía era el hoy.

No es un Constitución nueva la que allí se presenta. Es una Constitución antigua, histórica, tradicional, de raíces consuetudinarias en última instancia, construida con retales del pasado, con dispositivos e instituciones tomados del mundo pretérito que parecía disolverse: hay aquí una carta constitucional que carece de cláusula derogatoria porque no estaba en condiciones de (ni tenía el poder suficiente para) cancelar el caudal histórico que la nutría y la definía. Lo que se hace - y así lo dicen sus protagonistas a través de numerosos, esclarecedores e inequívocos testimonios- es afirmar instituciones y leyes antiguas, recuperarlas, fortalecerlas, y asegurar la aplicación del modelo monárquico y católico que venía existiendo en España desde tiempos medievales, dándoles a todas ellas una nueva sistemática que facilite su reconocimiento y evite su posible ocultación o ambigüedad de cara al inmediato futuro. Se toma el pasado, se busca un modelo pretérito operativo, se limpia de impurezas, al mismo tiempo que se dota a la vida pública de los instrumentos precisos que impidan cualquier deriva despótica, y se le da, por fin, un orden que permita su clarificación. El pasado no sólo es fuente de poder y de institutos; es modelo de lo que se tiene que hacer para eludir los peligros de la degeneración que se habían dado en tiempos mo- 
dernos con los Austrias, con los Borbones y, sobre todo, con sus despóticos ministros. Por eso, el pasado es útil: porque es fuente donde se encuentra todo lo que debe existir, $\mathrm{y}$, al mismo tiempo, es enseñanza que previene frente a posibles desvíos. Las piezas varias que integran Cádiz no son invención de las Cortes, ni de sus diputados; son creación de la Historia, son piezas más o menos identificadas en el pasado y con el pasado, lo que conduce a Dios como depositario último de todas las esencias constitucionales primarias en cuanto que creador del marco político al que ahora sus criaturas están dando una nueva disposición. Pensemos en el inicio del texto gaditano que, empleando una fórmula de promulgación típica del Antiguo Régimen, habla de un rey, Fernando VII, que lo es por la gracia de Dios, antes que por la gracia de la Constitución, lo cual viene después, y la jerarquía no es pacífica, ni neutral, sino plena de significación jurídica y política: el rey es la máxima autoridad terrena, pero debe su poder indiscutiblemente a ese Dios todopoderoso, Padre, Hijo y Espíritu Santo, autor y supremo legislador de la sociedad. Por medio de la Historia, de la que bebe la Constitución, hemos llegado a la Teología que es la que funda el orden político-jurídico, el orden constitucional resultante (más que querido, aceptado por los hombres que integran la Nación y, con ella, la Monarquía). Es una suerte de canto del cisne del Antiguo Régimen, en donde ese modelo político obsoleto y criticado tiene la suficiente capacidad y el suficiente arrojo como para condicionar el resultado normativo producido con el propósito de hacer perdurar esquemas viejos envueltos aparentemente en nuevas palabras y en nuevos conceptos, que de inmediato se quieren envejecer por motivos pragmáticos y de legitimidad. En vano. Tales palabras y tales conceptos no innovan en absoluto, sino que se reconocen en lo pretérito de forma clara y nítida. El orden jurídico del que se formaba parte no era algo monolítico, intocable, inmodificable e inmanejable. El Derecho del Antiguo Régimen procedía a evolucionar también, no obstante su origen divino, esto es, su perfección ínsita, a través de mecanismos internos de auto- o de regeneración, a partir de sus propios elementos consustanciales, que implicaban la suma, la adición, nunca la resta o la desaparición de elementos jurídicos, salvo casos excepcionalmente justificados por causa de pública utilidad o de necesidad, para que todos se imbricasen en el complejo orden coral ya construido. Todo estaba creado. Restaba al hombre simplemente el descubrimiento de ese Derecho, la mejora y defensa de esa creación divina o la corrección de las impurezas que la actividad humana hubiera podido introducir en el plan de Dios. Así se efectúa en el proceso que conduce a Cádiz: de lo antiguo se pasa a lo antiguo mínimamente reformado, enmendado, corregido o mejorado, que aparenta ser nuevo, sin llegar a serlo en su totalidad. Lo pasado se somete a un proceso de recomposición. Nada se pierde en el camino; nada se omite; nada se destruye o se desecha; nada se cambia en lo sustancial. Todo permanece bajo otras palabras, bajo otras rúbricas o en otras sedes. Se refuerza, en todo caso, su existencia para, de esta forma, asegurar una persistencia que permita cumplir con el espíritu de los nuevos tiempos y evitar las derivas tiránicas y despóticas de épocas anteriores. Y así se hace 
ciertamente. Recuperar y garantizar la pervivencia de lo recuperado. El pasado invade, pues, el presente de un modo indiscutible.

Ése era el incuestionable estilo de la época cultivado por nuestros ilustrados, los mismos que hallamos en Cádiz: el pasado como tabla de salvación, como mito tangible donde todo se encontraba en perfecto estado y al que el paso del tiempo y ciertas traiciones a un espíritu nacional sempiterno habían corrompido, por lo que era preciso una labor de depuración y de limpieza en varios frentes, id est, un proceso nunca constituyente, sino, a lo sumo, reconstituyente o reformista con mayores o menores intensidades, mas sin llegar a prescindir de los pilares esenciales sobre los que se había asentado todo cuanto éramos y todo cuanto teníamos que seguir siendo. Se buscaba, antes que nada, una regeneración de la Monarquía con todos los rasgos que la definían, una reparación, resurrección o refacción de la misma, pero sin que ésta fuese eliminada del panorama político-jurídico. La Monarquía tenía que ser recuperada en su versión más pura para luego ser ajustada a los nuevos tiempos y apuntalada con dispositivos que asegurasen su pervivencia milenaria. Y con la Monarquía iban anexos toda una serie de elementos de ella derivados y con ella fuertemente integrados, indispensables para asentarla y asegurarla en el sentido indicado. Debemos, pues, ponernos la gafas de 1812 para observar con todo lujo de detalles lo que en esa fecha tan señalada se estaba pergeñando para el destino inminente de la Monarquía hispánica y quiénes, cómo y por qué lo percibían así. Las discrepancias entre facciones vendrían determinadas por el alcance y profundidad de la reforma y por los tiempos de la misma, pero no por el cuerpo central y nuclear sobre el que se tenía que realizar aquélla, así como por los pilares básicos que, a lo sumo, deberían ser reforzados, mas nunca suprimidos. Un credo político común era compartido por todos los prohombres y diputados gaditanos y sobre aquel corpus heteróclito iban a pensar el mundo constitucional que querían reinstaurar.

Si nos atenemos a las premisas expuestas con anterioridad, la novedad más relevante que se puede formular, es la ausencia empírica, constatable, evidente y clara, de un autentico poder constituyente en las Cortes Generales y Extraordinarias, inauguradas en septiembre de 1810, entendido como poder originario, ilimitado y autóctono residenciado en la Nación (sí lo está, por el contrario, en la Historia y, por extensión, en Dios como fundador de aquélla), de lo cual se deriva la imposibilidad de calificar a la Constitución de 1812 como auténtica Constitución moderna, consecuencia de la suma de varias imposibilidades, rayanas con la impotencia. La imposibilidad, en primer lugar, de una Nación al estilo plenamente liberal, que debe reducirse a y contentarse con la presencia de una realidad nacional al estilo literario del Antiguo Régimen, dominada por las elites religiosas, militares y jurídicas, es decir, una Nación que no es libre, ni igual, ni fundada en el valor capital del individuo, sino integrada por cuerpos ancianos, partes varias de un mapa político heterogéneo, con gremios y corporaciones que silenciaban a las personas, nunca compuesto de ciudadanos plenos, ausentes en las grandes decisiones que allí se adoptan. De ahí 
se sigue la imposibilidad de una auténtica soberanía nacional debido a lo anterior, con la sombra omnipresente de ese monarca que subyace en cada una de las líneas de los debates o artículos constitucionales y que nos conduce hacia una suerte de soberanía cooperativa, compartida, fragmentada, pero no hacia una soberanía exclusiva de la Nación. Finalmente, derivado de los dos puntos anteriores, aparece una tercera restricción: la imposibilidad de una libertad absoluta de los diputados, dimanante de las singulares formas de representación actuadas, para trazar el guión del futuro sin ataduras con el pasado y para atreverse a romper con los legados más significativos que ese pasado traía consigo (algunos ya mencionados: la forma monárquica, los territorios, la religión católica), dado que Cádiz no cancela para nada lo pretérito, sino que se apoya e impulsa en el mismo para conseguir sus propósitos. La Historia sojuzga a la Nación, ya de por sí despedazada en cuerpos heterogéneos. Es una Constitución que se redacta con las puertas abiertas al ayer y a todo lo que el ayer significaba, que no lo depura más que en mínimas fracciones, sino que, mayormente, lo constitucionaliza y lo incorpora a su articulado, con correcciones, mejoras y reformas mínimas, casi imperceptibles, no sustanciales en todo caso, dirigidas a perpetuar ese legado pretérito por toda la eternidad, a hacerlo efectivo, vigente e inatacable, para que pudiera superar crisis tan duras como las que se estaban viviendo desde marzo de 1808 . Hay que mantener ese entramado de la Monarquía y no trastornarlo, ni alterarlo en la medida en que se pueda. Eso es lo que se hace desde 1810 y culmina en el mes de marzo de 1812. En ningún instante, como aconteció en Francia con la Revolución, hay intento alguno por parte de los redactores de hacer tabla rasa del pasado, de erradicarlo, de enviarlo al pozo de la Historia, de enumerar todo aquello que ya no habría nunca más en España, de explicitar un efecto derogatorio que brilla por su ausencia y justifica lo que ahora diremos. Y eso que Francia también manejaba una cierta cultura y discurso constitucionales de corte antiguo, pero de inmediato superados por la dinámica de los acontecimientos. No hay en el caso hispánico intención de marcar una cesura histórica con mayúsculas, de romper con el ayer, de protagonizar una fractura temporal expresa y decidida: al contrario, todo lo que figura en el articulado, como piezas más relevantes y esenciales (forma de gobierno, ciudadanía, religión, organización territorial, potestades, etc.), figura por el peso específico e indiscutible de la Historia a la que no se podía renunciar de ninguna de las maneras posibles, a la que no se podía combatir bajo el riesgo de dejar de ser todo aquello que históricamente había singularizado a España como Monarquía y como Nación. La Historia dicta el guión de la Constitución y ningún poder humano puede oponerse a la misma. El pasado es el que hace el presente y en él, en ese mundo remoto, se puede reconocer todo precepto constitucional. Es un espejo y es un modelo, como ya se ha avanzado. Si España quería ser algo en esas horas inciertas de 1812, tenía que serlo con, desde y a partir de la Historia, nunca a sus espaldas, nunca sin contar con ese flujo incesante procedente de tiempos remotos. Lo contrario habría supuesto el suicidio político como comunidad. 
Sin poder constituyente, esto es, sin una Nación libre que decide ponerse en movimiento para articular la soberanía como depósito de todo el poder público concentrado y llevarla así a su máxima expresión, a su más alta capacidad de decisión, sin un poder capaz de actuar sin vínculos imperativos y directos con el pasado más que aquellos que libremente se deciden asumir y conservar, sin un poder de esta naturaleza capaz de crear todo lo nuevo y de destruir todo lo antiguo, decíamos con anterioridad, no podremos encontrar resto alguno de Constitución moderna por ninguna parte y en ninguna de las direcciones en las que nos movamos. La Constitución, en su acepción moderna, está ausente porque adolece del autor que toda Constitución ha de tener, y porque carece de los elementos mínimos que le sirven como criterio de homologación respecto a sus coetáneas estadounidenses y francesas. No pretendamos buscar o ver en Cádiz ninguna Constitución porque Cádiz no nace como resultado de proclamación volitiva de poder constituyente alguno, un poder concebido al estilo de lo que ordenaban los cánones de los movimientos revolucionarios que habían triunfado en el siglo anterior. Hubo en aquellos lares un poder constituyente capaz de romper con el pasado, capaz de marcar la frontera entre el ahora y el ayer, y que, por eso mismo, enviaba al depósito de la Historia todo lo que ese pasado había supuesto sin posibilidad de regreso en ningún momento y bajo ninguna circunstancia. Era ese modelo de poder constituyente, tanto el americano como el galo, capaz de escribir un texto rotundamente nuevo que marcaba un antes y un después, que ponía puertas al tiempo para determinar lo que valía o lo que no valía, lo que era novedoso y útil, frente a todo lo antiguo e inútil, un texto que trazaba una clara separación entre el nuevo mundo constitucional y el viejo orden feudal, el cual pasaba a ser derrumbado, obviado y aniquilado, que devenía, por tanto, ser histórico, es decir, no vigente y, por ende, irrelevante desde las perspectivas jurídica y política. Fuera de la Constitución así concebida, tal y como hicieron americanos y franceses, sólo había antigüedades, despojos, restos, ruinas, materiales de desecho, productos que debían ser abandonados y erradicados, pero no podía aparecer, ni aparecía, materia constitucional viva alguna. Los tiempos que inauguraban las nuevas Constituciones eran, en efecto, tiempos nuevos porque abrían nuevos caminos de cara al futuro y sepultaban el pasado de una vez por todas. Cádiz era evidentemente otra cosa distinta.

Por tales motivos aducidos, Cádiz no puede ser jamás reputada como un fruto de la razón abstracta, como un producto del racionalismo iusnaturalista, como ejecutoria de una autoridad política absoluta (ya la Nación, ya la Monarquía con su rey a la cabeza, ya su confluencia coordinada), sino, más bien, todo lo contrario: fruto de la razón histórica, de esa razón que vive por y para el pasado, con el propósito de convertir al hombre en autorizado heredero de sus ancestros; producto de un historicismo de corte tradicional, basado más que en aquellas Constituciones al estilo revolucionario en aquellas otras Leyes Fundamentales, profundamente enraizadas en las estructuras políticas del ayer que definieron los límites del poder soberano casi absoluto y lo justificaron en todo su esplendor; y ejecutoria de un pasado que ejercía una influencia incontestable 
sobre el presente, que no era capaz de separarse de él, dado que en su seno contenía su esencia política indestructible. Cádiz no crea Constitución auténticamente novedosa; efectúa una reordenación de las Leyes Fundamentales del Antiguo Régimen, es decir, una revisitación o recomposición de los principios esenciales sobre los que se sustentaba la Monarquía Católica Hispánica, sin que se diese pie a la aparición de un poder originario, radical, drástico y omnímodo. En 1812, se procede a una recuperación, reinstauración y relectura del pasado hispánico (no solamente castellano), en clave de resurrección político-jurídica de todo aquello que había existido en tiempos remotos de plena felicidad constitucional y que, por distintas razones, causas y azares, se había perdido en el tiempo intermedio.

No hay creación sin tradición. Los clásicos lo comprendieron bien cuando trazaron una línea de clara separación entre la traditio y la imitatio. Lo nuevo es, en realidad, la nueva forma de conjugar todo aquello que nos precede en el tiempo; es el modo específico que cada época tiene de enfrentarse, de leer, de comprender y de interpretar lo pretérito común. La novedad no es más que una versión peculiar del pasado. Las vicisitudes constitucionales gaditanas parecen dar la razón a este último aserto, a esta dinámica de revisión o de revisitación de los fundamentos políticos de la Monarquía con la clara intención de hacer que perdurase en el tiempo hasta alcanzar la inmortalidad. Se equivocaba el recordado F. Tomás y Valiente cuando explicaba el momento gaditano como el paso de muchas Leyes Fundamentales a una sola Constitución, afirmando, pues, la vigencia de una práctica constituyente: lo que hubo, en realidad, fue el tránsito de muchas Leyes Fundamentales a otras tantas Leyes Fundamentales (esencialmente las mismas), pero ya recogidas en un solo texto, mejor ordenadas, sintetizadas y clarificadas, y con importantes ajustes institucionales para su salvaguardia. Nada más y nada menos, puesto que la tarea así reputada no dejaba de ser titánica y dificultosa. La pretendida cabeza moderna apenas tenía las fuerzas necesarias e indispensables para regir los destinos de ese cuerpo esencialmente gótico, que era el que, al final, acabó por dirigir toda la maquinaria política, todo el sistema reconstituido.

Tras su aprobación, promulgación, publicación y juramento, la Constitución comienza su andadura que se ve abruptamente concluida dos años después. Oigamos las palabas de Fernando VII:

Declaro: que mi Real ánimo es no solamente no jurar ni acceder á dicha Constitución ni á decreto alguno de las Córtes generales y extraordinarias, y de las ordinarias actualmente abiertas, á saber los que sean depresivos de los derechos y prerogativas de mi soberanía, establecidas por la Constitución y las leyes en que de largo tiempo la Nación ha vivido, sino el declarar aquella Constitución y tales decretos nulos y de ningún valor ni efecto, ahora ni en tiempo alguno, como si no hubiesen pasado jamás tales actos, y se quitasen de en medio del tiempo, y sin obligación en mis pueblos y súbditos de cualquiera clase y condición, á cumplirlos ni guardarlos ${ }^{5}$.

${ }^{5}$ Cfr. M. Fernández Martín, Derecho parlamentario español, Madrid, 1992, tomo II, pp. 856-863. 
La Constitución termina por ser eliminada, anulada, despojada de su valor en cuanto que texto compilatorio de aquellas Leyes Fundamentales. Lo que hizo Fernando VII con su Decreto de 4 de mayo de 1814 fue un golpe de efecto para recuperar la voluntad política primera (única y exclusiva) que la Constitución le obligaba a compartir a la luz de la Historia. El monarca entendía que, en su peculiar lectura del pasado, los diputados de las Cortes se habían equivocado y extralimitado, habían errado el diagnóstico pretérito y, en consecuencia, habían formalizado un texto plagado de malentendidos y excesos que se compadecía muy mal con las antiguas Leyes Fundamentales, inclinando nuestra Constitución hacia una alteración de esas buenas, justas y sabias normas históricas y hacia una innovación peligrosa consistente en copiar los principios revolucionarios y democráticos de la Constitución francesa de 1791, rechazando de plano los inherentes a una Monarquía moderada que eran los tradicionalmente vinculados a España. A partir de ese instante en que la Constitución es sacrificada por el Deseado, se multiplica exponencial y radicalmente la forma de ver y de percibir ese texto, destacando, como vamos a tener la oportunidad de exponer a continuación y de forma breve, tres lecturas como aproximaciones al mundo gaditano inmediatamente subsecuentes al propio documento constitucional: la afrancesada (crítica con la Constitución por sus excesos o por sus insuficiencias a la francesa), la catequética (lectura ingenua y didáctica del texto) y la historicista (defensora del claro entronque con la Historia patria del corpus de 1812). Como no había instrumentos que asegurasen la primacía de alguna de ellas, resultó de todo esto que, en principio, cualesquiera de tales visiones podían ser compatibles entre sí y perfectamente válidas y operativas. O dicho de otra manera: todos tenían razón en sus discursos porque era cuestión de perspectivas y de ángulos de visión. No había verdades absolutas respecto al texto. Todos los enfoques eran óptimos porque todos se reconocían en ella y tenían parte de razón. La Constitución, es decir, aquellas viejas y veneradas Leyes Fundamentales, era la misma, siempre y en todo lugar. Cambiaba el prisma con que se observaba y el punto de vista desde el cual se oteaba su contenido. Veamos cómo operó cada una de estas lecturas.

El afrancesamiento deviene lugar común y acaso primario entre todas las críticas que sufre la Constitución de 1812. Es la primera objeción que viene a la mente por similitudes incontestables, textuales aunque no conceptuales, pues es aquí donde se rompe el vínculo con lo que aconteció más allá de los Pirineos. Se tilda a aquélla de ser simple remedo, copia o versión de las Constituciones francesas, con lo cual se está negando su engarce con las tradiciones nacionales españolas. Al mismo tiempo que se refuta esa ligazón nacional, lo cual era ya de por sí grave, se añade otro condicionante negativo: copia lo francés. El pecado es doble: no es texto nacional, se aparta de lo patrio, y además toma elementos del extranjero más repudiado, toma del exterior el modelo más execrable de todos cuantos existen. No debe olvidarse quién era el principal enemigo político y militar de España en esos momentos. Para destrozar cualquier labor de las Cortes, bastaba deslizar esas similitudes con los patrones 
galos y desmontar así sus logros. Esta tendencia no es patrimonio de ningún grupo en concreto. Hay ejemplos de todo signo, pero, sobre todo, descuellan los procedentes de las propias filas afrancesadas (donde se encuentra una crítica con cierto tono y querencia positivas, alabando esa aproximación insuficiente hacia lo que consideraban el único cuerpo reformista capaz de sacar a España de su marasmo ya secular) y de las filas absolutistas (en sentido totalmente inverso al anterior). Unos critican por defecto y los otros por exceso. Esta segunda dirección es mayoritaria y de presencia sustancialmente clerical ${ }^{6}$. Sin embargo, ambas visiones adoptan un estilo similar de presentación de tales parecidos, aunque la conclusiones a las que llegan no lo son: la comparación, artículo a artículo, entre la Constitución gaditana y las Constituciones francesas (especialmente, la de 1791) para mostrar con descarnada delectación el plagio detectado, totalmente opuesto a la tradición española y a lo que las Cortes decían que habían hecho, conforme al guión trazado, entre otros documentos, por el Discurso Preliminar. Se quiere mostrar así que las Cortes han claudicado porque han tomado de fuera lo que ya había aquí, han alterado la tradición, repudiando la propia y abrazando la ajena, y además han mentido de forma deliberada puesto que decían que la Constitución era una cosa tras haber hecho otra radicalmente diferente. Han envuelto sus palabras de puro engaño para reducir los riesgos de la ruptura que estimaban se podría producir al tomar los términos y conceptos franceses en su estado más puro y trasladarlos a la realidad hispánica. El gallego B. Ma . Sotelo Noboa y Niño dirá a este respecto me lisonjeo de que qualquiera que se ocupe en leerlas y meditarlas (las observaciones que hizo imprimir en El Sensato), podrá responder con conocimiento al Redactor que osadamente pregunta, si la Constitucion es una cosa nueva, ó estaba en nuestras leyes, que podrá, sin necesidad de largas investigaciones, enterarse de que la Constitución que se nos ha dado es una tarazea mal zurcida de las del 91 y 5 mesidor de los franceses, como no ignoran, como es notorio á los que entre nosotros se han tomado el trabajo de exâminarla! ${ }^{7}$. Mezcla confusa y convulsa de los textos constitucionales franceses, carente de originalidad, pero, sobre todo, carente de cual-

\footnotetext{
${ }^{6}$ Vid. M. Artola, Los afrancesados, con prólogo de Gregorio Marañón, Madrid, 1953; E. La Parra López, El primer liberalismo español y la Iglesia. Las Cortes de Cádiz, Alicante, 1985; y M. Moreno Casado, El clero afrancesado en España. Los obispos, curas y frailes de José Bonaparte, epílogo de Miguel Artola, Madrid, 2014.

${ }^{7}$ Cfr. B. Ma. Sotelo Noboa y Niño, ¿Qué era la Constitucion? Ó sea observaciones sobre la que sancionaron las Cortes Generales y Extraordinarias, publicadas en 1812, y reimpresas ahora de nuevo en un solo volumen por su autor D. Benito María Sotelo de Noboa y Niño, Marqués de Villaverde, \&c. \&c. $\&$ c., Caballero Maestrante de Ronda, vecino y Regidor perpetuo que era de la Ciudad de Orense, y como tal Diputado por la misma Provincia, é individuo de la primera y Suprema Junta del Reyno de Galicia en 1808, Madrid, 1814, p. 7 y pp. 177-202, con uso prolífico de los DSCGE y del Discurso Preliminar (las Observaciones se publican inicialmente en El Sensato. Periodico de Santiago de Galicia, editado en Santiago de Compostela, entre los días 6 de febrero y 21 de mayo de 1812, correspondiente a los números 25 a 38 de la citada publicación, siendo después reimpresos con nuevas anotaciones recogidas a pie de página en el volumen por el que se cita).
} 
quier conexión con el mundo hispánico, de cualquier vínculo con el mundo político de estas tierras. No puede cuajar. No puede crecer e implantarse. No puede echar raíces. Esto justifica y simplifica su posible erradicación para volver al universo previo del Antiguo Régimen. Allana el camino a tales propósitos. Los anónimos autores del Examen analitico de la Constitucion politica publicada en Cádiz en 18 de marzo de $1812^{8}$ y de las Sencillas reflexiones á varios articulos de la Constitucion politica de la Monarquia española publicada en Cádiz á 19 de marzo de 1812. Por las que se prueba lo confusa, inutil y perjudicial que era á los pueblos ${ }^{9}$ caminan en la misma dirección. El primer texto quiere demostrar que el sistema político constitucional no está conformado de acuerdo con los principios de la teoría del gobierno representativo, ni combinado con el carácter nacional y las luces de la experiencia. No se ha adaptado plenamente a España y a sus rasgos consustanciales, lo cual trae como resultado el riesgo de la anarquía al que se expone la libertad política, presta a ser aniquilada: Los legisladores de Cádiz, imitando el modelo de la Constitución francesa de 1791, no sólo no han acomodado los principios del gobierno representativo al carácter nacional, sino también los violaron omitiendo la institución de una autoridad reguladora de las potestades que componen el sistema politico. Ambas condiciones hubieran producido igual grado de libertad política sin el peligro de la anarquía. En el segundo texto citado, se comentan el preámbulo y diversos artículos del texto gaditano para reafirmar, como punto de partida inexcusable, que se han adoptado y copiado las Constituciones francesas, singularmente la del año 1791, y esto ha provocado el difícil encaje de esos preceptos procedentes de allende los Pirineos con el modelo monárquico que se vivía desde hacía tiempo en tierras hispánicas: en palabras de su autor, lo que se proponía era presentar una suerte de memorial para mostrar que la Constitución no era tan completa y útil como se quería persuadir, y que merecía interpretarse y corregirse en muchas cosas, si es que no pareciese justo anularla del todo. Por supuesto, los calificativos de texto divino o sacrosanto estaban totalmente fuera de lugar e incluso insinuaba que la Constitución se ha anulado, no porque ella no fuese en sí buena, sino por la fuerza y sugestiones de los enemigos de

\footnotetext{
${ }^{8} \mathrm{Cfr}$. Examen analitico de la Constitucion politica publicada en Cádiz en 18 de marzo de 1812, Madrid, 1813, passim, pero especialmente, pp. 55-56, donde se fijan conclusiones en tal sentido, después de un riguroso análisis comparativo: se critica el monocameralismo y la necesidad de una autoridad intermedia entre la potestad legislativa y la ejecutiva, así como las restricciones al poder del rey, lo que conducirá a éste a una oposición de la cual nacerán desconfianzas, sospechas y acusaciones de despotismo, y acabará todo en tremendas convulsiones. El autor merece severo reproche de F. Martínez Marina, en su Teoría de las Cortes, ó Grandes Juntas Nacionales de los Reinos de Leon y Castilla. Monumentos de su Constitucion Politica y de la Soberanía del Pueblo. Con algunas observaciones sobre la Lei Fundamental de la Monarquia Española, sancionada por las Cortes Generales y Extraordinarias, y promulgada en Cádiz á 19 de marzo de 1812 (Madrid, 1813), tomo I. Primera Parte, pp. 191-192.

${ }^{9} \mathrm{Cfr}$. Sencillas reflexiones á varios articulos de la Constitucion politica de la Monarquia española publicada en Cádiz á 19 de marzo de 1812. Por las que se prueba lo confusa, inutil y perjudicial que era á los pueblos, Madrid, 1814, Introduccion á estas reflexîones, pp. I-IV y, sobre todo, pp. 7-39.
} 
las reformas. Así, por ejemplo, al glosar el artículo 368, en el que se disponía que la Constitución tendría que explicarse en las universidades y establecimientos literarios donde se enseñasen las ciencias eclesiásticas y políticas, se dice que dicho precepto muestra a las claras que la Constitución citada no era un texto claro y como son pocos los españoles que pueden concurrir á ellos (a los citados establecimientos literarios) serán varias las interpretaciones y explicaciones, y serán infinitos los que ignoren ó no entiendan este código tan elemental y ponderado; y no entendiéndole ¿cómo podrá culpárseles de su inobservancia? poniendo el dedo en la llaga de las plurales lecturas a las que el texto gaditano iba a dar lugar.

Más famosas son las exposiciones de J. A Llorente ${ }^{10}$ y de F. de Alvarado, el Filósofo Rancio ${ }^{11}$, quienes se detienen, por encima de todo, en las circunstancias específicas en las que el texto constitucional fue redactado para rebajarle o privarle de modo directo de todo su valor político y jurídico por carecer de los mismos las Cortes que lo actuaron, hasta llegar al que, sin duda, es el ejemplo más conocido y drástico de todos ellos, el del padre Rafael de Vélez ${ }^{12}$, quien, tras efectuar una comparación de

${ }^{10}$ Cfr. J.A. Llorente (J. Nellerto), Memorias para la historia de la revolucion española, con documentos justificativos, Madrid, 1814, tomo I, passim.

${ }^{11}$ Aunque anteriores a la Constitución de 1812, si bien publicados posteriormente, cfr. F. de Alvarado, Constitucion filosofica que el Filosofo Rancio transformado en Filosofo Liberal, escribió ántes que las llamadas Córtes Extraordinarias sancionasen su Constitucion politica para la Monarquia española. Sevilla, 1816, Primera Parte, pp. 31-39 (= también en I. Fernández Sarasola, Proyectos constitucionales en España (1786-1824), Madrid, 2004, pp. 702-704); y además las Cartas Críticas que escribió el Rmo. Padre Maestro Fr. Francisco Alvarado, del Órden de Predicadores, ó sea el Filósofo Rancio, en las que con mayor solidez, erudicion y gracia se impugnan las doctrinas y máximas perniciosas de los nuevos reformadores, y se descubren sus perversos designios contra la Religion y el Estado. Obra utilísima para desengañar a los incautamente seducidos, proporcionar instrucciones á los amantes del órden, y desvanecer todos los sofismas de los pretendidos sabios (Madrid, 1824), tomo I, carta I, pp. 32-33.

${ }^{12}$ Primeramente, en su Preservativo contra la irreligion. Ó los planes de la filosofia contra la religion y el estado, realizados por la Francia para subyugar la Europa seguidos por Napoleon en la conquista de España, y dados a luz por algunos de nuestros sabios en perjuicio de nuestra patria, Cádiz, 1812 (reimpreso por vez primera en Madrid, en 1812-1813, hasta en cuatro ocasiones, y, en segunda instancia, en Santiago de Compostela, 1813). Citamos por la edición de Madrid, 1825, en concreto, $\mathrm{n}^{\circ}$ VI, pp. 123227, para poner de manifiesto la inmoralidad francesa que, como un plaga, amenaza con asolar España entera; y, sobre todo, en su Apologia del altar y el trono, ó historia de las reformas hechas en España en tiempo de las llamadas Cortes, e impugnacion de algunas doctrinas publicadas en la Constitucion, diarios y otros escritos contra la religión y el estado, Madrid, 1818, tomo II, capítulo IX, pp. 173-196, con la expresiva rúbrica La constitucion de Cádiz esta copiada en su mayor parte de la de los asambleistas de Paris. Sigue en Capítulo X, pp. 197-204, con duras críticas a las contradicciones del articulado constitucional y a su intento de restringir los poderes del monarca, de atacar al trono y someterlo al imperio de la soberanía popular, "acaso sin conocer sus autores, que un trono degradado, ó un rei sin poder competente, es una autoridad aérea, sin representación, sin ascendiente sobre los pueblos, y siempre espuesta a desaparecer al mas leve vaivén, á una vicisitud momentánea, ó á una convulsion de cuatro particulares, cuando ellos la quieran hacer. La constitución de Cádiz daba un poder mui reducido á nuestros reyes; estos estaban siempre pendientes de las córtes, ó de su diputación; para mui poco gozaban de absoluta libertad. Un poder precario implica con un poder real: si el rei no goza éste en toda su plenitud, 
artículos y demostrar la identidad entre las Constituciones gaditana y francesa, concluye diciendo que los fastos que han seguido a la aprobación de la primera (medallas, monedas, mármoles, monumentos, elogios de la prensa) no han servido de nada y no han podido ocultar la cruda realidad: Toda la pompa y magestad de que era capaz nuestra nación, se dedica toda á ponderar el mérito de nuestros legisladores y de su sagrada carta, del sagrado código, de la sagrada constitución ... ¿Tengo derecho para decir, amadores de las reformas, os engañásteis con la constitución? ... Ah ... ¡constitucionistas, celebrasteis con locura la constitución de Francia! ¡reformadores, os hicisteis, asambleistas, tal vez sin llegarlo á advertir! Todos se han engañado y todos han vivido en la simulación. España carecía de gobierno, de ley estable, de autoridad, con particulares que mandaban y superiores obligados a ceder, donde cada uno hacía lo que le agradaba puesto que todos eran árbitros de la ley para entenderla á su gusto, y aplicarla á su placer. Era pura anarquía lo que se vivía bajo el mando (por llamarlo de alguna manera) de la Constitución: no era una ley fija, carecía de contundencia conocida, de poder competente, sin arbitrio para sostenerse o hacerse entender a los súbditos. Provocaba, en suma, insubordinación, divisiones, fracturas y el más completo caos: lo que se vivía era una anarquia cimentada en una constitucion, incapaz de equilibrar la necesidad de un poder fuerte con la libertad de los ciudadanos. El traslado literal y conceptual de lo francés había provocado este resultado. Se copiaban las palabras, pero también las ideas y éstas no tenían cabida en el mundo hispánico, so pena de destruirlo. Iban contra su esencia histórica. Había que abandonar tal funesto ejemplo y retornar al momento político previo. Extirpar lo foráneo, lo que significaba volver los ojos a lo propio. Se confiaba en la restauración y en la erradicación del recuerdo gaditano porque todo en él evocaba a la Francia napoleónica.

No es de extrañar que la acción derogatoria fernandina de 1814 tuviese como sustento las opiniones de algunos de los anteriores, sobre todo, del padre Vélez que dedicó su Apología precisamente a Fernando VII. Pero eso no significaba obviar a las Cortes, a las viejas Leyes Fundamentales integrantes de la Constitución, a la Historia, al pasado, ni mucho menos. Porque lo que se había hecho hasta ese momento, se había hecho precisamente a partir de todo ese caudal previo y contando con él. El fondo sobre el que las Cortes y el monarca dialogaban era el mismo. El rey habla de Leyes Fundamentales, las mismas que invocaron los diputados gaditanos para actuar en el plano político. Lo que había que decidir era quién (si el rey, las Cortes o ambos) estaban legitimados para efectuar esa condensación constitucional y, sobre todo, para introducir las mejoras, enmiendas y providencias pertinentes a los efectos de asegurar ese uni-

en vano son los jueces, en vano son las leyes, en vano es la misma constitución”, y en II. Capítulos XI, XII, XIII, XIV, XV, XVI y XVII, pp. 204 ss., con narración de las violaciones y atropellos cometidos por las Cortes, cuya responsabilidad última corresponde a la Constitución, igual a la de Francia, culpable principal de la anarquía y perpetua revolución que vive España puesto que la ha fraccionado en partidos y ha convertido a cada hombre en soberano. Con mayor detalle, cfr. II. Capítulo XV, pp. 257-277, en donde no olvida la influencia francesa, en lo intelectual y en lo textual. 
verso de leyes básicas. Era un problema, a nuestro juicio, no de contenidos, sino de decisiones: no de fondo constitucional, sino de articulación de la suprema capacidad de decisión. Un problema, en suma, exclusivamente político, volitivo, del querer, decisional en estado puro, pero no jurídico, relativo a los contenidos. Fernando VII podía comulgar prácticamente con todo lo que la Constitución vertía en papel, dado que nada se inventaba o innovaba. Ni le daba, ni le quitaba nada, sino que simplemente le recordaba y le imponía como ley constitutiva cómo había de comportarse un perfecto monarca católico, le informaba de cuáles era sus viejos derechos y obligaciones, su modo de conducirse de ahí en adelante, cosa que no siempre se había hecho y cosa que el monarca no siempre había respetado. Lo que no podía consentirse es que fuese la Nación la que fijase las reglas de la Monarquía aprovechando su ausencia. La excepcionalidad del momento gaditano debe recorrer el camino de vuelta y trasladar el centro del discurso político a la persona del rey, nunca a la de la Nación. Ésta ha actuado en circunstancias extremas que ahora han desaparecido. El debate MonarquíaNación seguía activado. Ése era el principal problema a dilucidar. No sorprende así que el pensamiento liberal, el reaccionario y el absolutista sigan moviéndose dentro del mismo universo de tópicos empleado por los diputados gaditanos. Sus referencias intelectuales eran las mismas y la coincidencia no era casual. Cambiaban los desarrollos que no eran más que formas diversas de interpretar el caudal histórico remanente. De la misma manera que Jovellanos y Martínez Marina habían discrepado cordialmente acerca del sujeto rector de la dinámica política en los inciertos momentos que siguen al año 1808, ese dilema seguía sin resolverse a la altura de 1814. Monarquía o Nación, Rey o Cortes, seguían siendo los antagonistas antes de que se produjese su fusión o perfecta imbricación por obra el pensamiento moderado ${ }^{13}$.

El convencimiento de que la Constitución no había sido más que una recuperación y una reforma de esas antiguas Leyes Fundamentales no fue una simple estrategia de las Cortes o no fue solamente eso. Hay algo más subyacente. Era opinión compartida y difundida. La publicística del momento, dentro de la cual ocupan un lugar de importancia los catecismos constitucionales, piezas dirigidas a crear ciudadanos españoles perfectamente incardinados y educados en el tradicional orden político y

\footnotetext{
${ }^{13}$ Para el contexto ideológico de esta primera restauración absolutista, vid. M. C. Diz-Lois, El Manifiesto de 1814, Pamplona, 1967; J. Varela Suanzes-Carpegna, "La teoría constitucional en los primeros años del reinado de Fernando VII: el Manifiesto de los Persas y la Representación de Álvaro Flórez Estrada", en AA. VV., Estudios dieciochistas en homenaje al Profesor José Miguel Caso González, Oviedo, 1995, tomo II, pp. 417-426; y La monarquía doceañista (1810-1837). Avatares, encomios y denuestos de una extraña forma de gobierno, Madrid, 2013, cap. 4, pp. 193 ss.; A. Rivera García, Reacción y Revolución en la España liberal, Madrid, 2006, pp. 33 ss.; J. M. Nieto Soria, Medievo constitucional. Historia y mito político en los orígenes de la España contemporánea (ca. 1750-1814), Madrid, 2007, pp. 173 ss. y Epílogo documental, pp. 189-209; y J. López Alós, Entre el trono y el escaño. El pensamiento reaccionario español frente a la revolución liberal (1808-1823), Madrid, 2011, pp. 167 ss. y pp. 241 ss. Sobre el destino posterior gaditano, a nivel hispánico, europeo y americano, vid. I. Fernández Sarasola, La Constitución de Cádiz. Origen, contenido y proyección internacional, Madrid, 2011, pp. 271 ss.
} 
teológico puesto por escrito en $1812^{14}$, defendió a capa y espada este resultado final de las Generales y Extraordinarias. Acaso se trata de la versión más ingenua y sencilla de todos los argumentarios manejados, pero no debe olvidarse su extraordinario éxito editorial y su difusión en uno y otro continente. Breves, honestos y sinceros, compendiosos, elementales, de reducidas dimensiones, sin lugar a dudas; eficaces y directos, por encima de todas las cosas, por su mensaje inmediato, concluyente y reiterativo, expuesto además de una manera clara y llana. En ellos se dan la mano lo religioso y lo político porque se acaba por concluir que el buen cristiano es el buen ciudadano y viceversa. La formación de los dos se hace con el mismo instrumento, con las mismas lecturas, y el provecho redunda en beneficio de la Iglesia y del Estado. Los catecismos prueban el vínculo estrecho entre Constitución y Religión, que el propio texto consagraba en su art. 12, así como el empleo de los conductos religiosos para la trasmisión y traslación de los mensajes políticos, dado que eran los únicos cauces que aseguraban una comunicación fluida con la totalidad de la población. Ayunos de Estado y de Administración, había que recurrir a la Iglesia como cuerpo político más uniforme, más perfecto, más universal, que llegaba a todos los rincones de la Monarquía, sin excepción ninguna. El catecismo no es más que la expresión última de esa Religión de Estado que preside todos los artículos gaditanos y todas las ceremonias ligadas a ellos, que inunda de referencias al catolicismo cada paso que dan los nuevos ciudadanos o las nuevas-viejas instancias de poder: el preámbulo de la Constitución, la confesionalidad de la Nación, las elecciones en cada uno de sus niveles, los juramentos de todas y cada una de las autoridades, etc. Demuestran asimismo que la Constitución era el fruto de los acuerdos y pactos de unas elites militares, políticas, jurídicas e intelectuales que nada tenían que ver con el resto del pueblo. Su carácter elevado requería de una traslación a román paladino. Era preciso inculcar a todos los restantes miembros de la comunidad sentimiento constitucional, valores y principios plasmados allí, y hacerlo de una forma barata, asequible y didáctica a raudales. Los resultados se cumplieron con creces y ayudaron a mostrar la Constitución como continuidad de viejas Leyes Fundamentales, en ocasiones, no siempre, y en un tono cotidiano, cercano, vulgar, alejado de la beligerancia anteriormente vista en Vélez y compañía. Al pueblo había que tratarlo con ternura y proximidad, sin tecnicismos, ni divagaciones complejas; los catecismos fueron el dispositivo perfecto para este cometido. Como todo el mundo letrado podía hacer un texto de estas características, son variados los discursos que los presiden y dirigen, puesto que se hallan en los mismos desde invocaciones a la persistencia de las ancianas estructuras de la Monarquía hasta cuidadas reflexiones sobre la soberanía de la Nación. Hay de todo en esas pequeñas píldoras constitucionales, destinadas a educar y a educar de un modo indiscutible, fructífero y duradero.

\footnotetext{
${ }^{14}$ Sobre los mismos, vid. P. García Trobat, Constitución de 1812 y educación política. Madrid, 2010. Para otras latitudes, igualmente dependientes del legado gaditano, vid. el excelente trabajo de M. A. Cocchiara, Catechismi costituzionali nella Sicilia costituente (1812-1848). Milano, 2014.
} 
Un discurso claramente histórico, por continuista, por engarzar con las tradiciones góticas y medievales, aparece ya en las primeras manifestaciones del género, en donde no se muestra con claridad a la Nación como protagonista principal, sino que sigue siendo el rey, un rey paternalista y protector, el que se encarga de guiar a sus súbditos, si bien no de una forma absoluta o caprichosa, sino con muchas limitaciones y condicionantes procedentes de los tiempos antiguos ${ }^{15}$. Hallamos ese mismo compendio de ideas, más elaborado y mejor construido, en otro texto procedente de tierras mexicanas, poniendo ya el acento en la Nación a la que se somete a envejecimiento deliberado: se reivindica el papel de las Cortes no sólo en Castilla, sino también en Cataluña, Aragón, Valencia y Navarra, y se afirma que cuando las Cortes tuvieron mayor autoridad, mayor perfección adquirió aquella anciana Constitución de España, aunque aquéllas tenían muchos defectos (representación incompleta; elección por los ayuntamientos o concejos, no nacional, por ende; dependencia de la voluntad del rey). No obstante lo cual, se insiste en que no hay riesgo de despotismo con una Monarquía en acción así construida debido a la restricción decidida que las Leyes Fundamentales, las que forman la Constitución de un Estado, operan sobre ese poder: el gobierno monárquico constitucional es aquel gobierno monárquico, justo, reglado por las leyes fundamentales, que hemos dicho forman la constitución de un estado, $y$ sin las quales no seria gobierno monárquico, sino despótico ${ }^{16}$. Más rupturista es la Cartilla natural y política del ciudadano español, en la cual se detallan derechos y libertades naturales (libertad, propiedad, seguridad, igualdad) y se afirma la soberanía de la Nación, si bien se admite la delegación de su acción o ejercicio en la figura del rey ${ }^{17}$. A pesar de ello, la noción de Constitución política que se sostiene en dicho escrito, de tono marcadamente anti-napoleónico, encaja mejor en el ambiente del siglo XIX que en el del siglo XVIII, es decir, es propiamente liberal y no ilustrada: una Constitución política y de la Nación, representada en un soberano congreso nacional, consiste en el modo que tenga para expresar su voluntad y hacer executar lo resuelto por esta voluntad en todas sus partes y en todos sus casos [...] es aquella ley ó conjunto de leyes que ella ha hecho por sí ó por sus representantes, para arreglar los tres poderes politicos, legislativo, executivo y judicial, determinando las circunstancias necesarias para el goze del derecho de ciudadano, el modo con que ha de nombrar sus representantes y expresar su voluntad para que sea ley, los medios señalados al poder executivo para hacerle executar y cumplir, tanto en lo interior como en el exterior; el número, órden y atribuciones de los tribunales, clase de jueces, la forma de su nombramiento, su dependencia y responsabilidad: y finalmente la constitucion determina las relaciones de los tres poderes entre sí, y las instituciones propias para

${ }^{15}$ Cfr. Catecismo Catolico-Politico que, con motivo de las actuales novedades de España, Dirige y dedica a sus Conciudadanos un Sacerdote amante de la Religion, afecto a su patria, y amigo de los hombres, Madrid, 1808, pp. 32-33, 41-44 y 46, a modo de ejemplo.

${ }^{16}$ Cfr. Catecismo politico para instrucción del pueblo español, México, 1811, pp. 2-3, 11-12, 14 y 16-19.

${ }^{17}$ Cfr. Cartilla natural y politica del ciudadano español. Coruña, 1812, pp. 51 ss. 
ser mantenida en su fuerza y vigor, y hacer respetar los derechos naturales del hombre. En suma, la Constitución, y ahora aflora un cierto regusto anticuario, es el código de leyes fundamentales ${ }^{18}$ : la que se está elaborando en Cádiz, dice el anónimo autor de la Cartilla, será una buena Constitución por la sabiduría e ilustración de los diputados que aprovecharán las lecciones de la Historia y de todo lo bueno que encierran las constituciones de los estados antiguos y modernos en especial de los buenos establecimientos para mantener la que formen. Dependencia de la Historia, pero a modo de maestra que da ejemplo y opera como modelo, insinuando un texto radicalmente nuevo en el escenario constitucional ${ }^{19}$.

Ejemplos que se debaten entre el sentimiento nacional y el monárquico aparecen por doquier. El Catecismo cristiano politico compuesto Por un magistrado, para la educacion de su hijo defiende el respeto y sumisión al monarca como pieza esencial de la maquinaria publica y muestra un cariz regio muy paternalista: $Y$ al Rey que debemos? El mas profundo respeto y sumisión por que es el que gobierna esta misma patria: trabaja y se desvela por su conservación y fomento, y como amoroso padre nos dirije al mismo objeto, y nos presenta sus virtudes para que nos miremos en ellas, como en un espejo; y considerando por esto su augusta persona, como designada por Dios, debemos confiar en sus aciertos y obedecer su leyes con respeto y amor según nos manda el mismo Señor, y exige la Constitucion de la sociedad ${ }^{20}$. En el extremo opuesto, aparece el Breve catecismo politico-español-constitucional, que a imitacion del de doctrina cristiana compuesto por el Señor Reynoso, presenta al publico E. D. D. E. A., donde se afirma que la Constitución nos ha sido dada para redimirnos y preservarnos del despotismo, de la arbitrariedad y de los restantes vicios, que se había hecho generales entre los gobernantes, como el pecado que heredamos de Adán, para enseñarnos con la doctrina cuáles son los derechos del hombre libre que vive en sociedad, y así para mostrarnos las Córtes el grande amor que nos tenían, y librarnos de los que de qualquiera manera nos esclavizaban, y de las degradaciones á que habiamos venido por nuestra ignorancia y agena voluntad. Se busca recuperar libertades y derechos perdidos, sepultados por varios siglos de despotismo, y concordar así con el discurso que la Cortes han hecho suyo. Sin ese texto, hubiésemos quedado enemigos de la humanidad y de nosotros mismos, esclavos de Napoleón, que es poco menos que el Demonio, desterrados del mapa de Europa para siempre, condenados

\footnotetext{
${ }^{18}$ Cfr. Cartilla, ed. cit., pp. 54-55. Hay algunas invocaciones a la antigua Constitución, en pp. V-VI, IXXII, 61-63, 68-69, 135, 145-146, 160 y 166-167, pero con ánimo de superación, no de recuperación, como cita o adorno histórico, casi arqueológico. Del mismo modo, se critica abiertamente la Constitución o Estatuto de Bayona, pp. 63-66, "la peor constitución que se ha escrito hasta ahora", "enteramente execrable, é indigna de ser admitida ni imitada".

${ }^{19}$ Cfr. Cartilla, ed. cit., p. 66.

${ }^{20} \mathrm{Cfr}$. Catecismo cristiano politico compuesto Por un Magistrado, para la educacion de su hijo. Lo da á luz El Ayuntamiento de Antequera, para educacion en sus escuelas. Antequera, 1814. Cap. XII, pp. 35-36.
} 
al último suplicio y destinados al Infierno ${ }^{21}$. La Constitución es la base de todo bien social (para cumplir con los deberes, para desterrar las bárbaras ilusiones, para hacernos dignos del nombre español), para cuyo sólido asentamiento se precisa de fe, esperanza política y amor patriótico ${ }^{22}$.

Empieza a calar esa idea de restitución de viejas Leyes Fundamentales, con mirada hacia el pasado medieval y deseo de no revivir nunca más los intermedios siglos de ignorancia y desconocimiento de nuestra Constitución que han conducido a la Monarquía a sus peores experiencias y resultados: si aquella Constitución se observa en todos su extremos, no podrá sucedernos nunca una desgracia semejante a la invasión francesa y a la subsiguiente tiranía de allí derivada, aunque ya perfilada o fomentada en tiempos anteriores entre nosotros mismos. Las Cortes son el freno esencial para detener estas derivas políticas, la pieza básica de este sistema nuevo, que acaba por encumbrar los derechos imprescriptibles de los hombres. Con ella, se conseguirán la felicidad y la libertad civil, las cuales permitirán a los españoles ser por necesidad industriosos, ricos y sabios, y, al mismo tiempo, asegurarán la independencia política para siempre jamás ${ }^{23}$. Para D. J. Corradi, la Constitución, como colección ordenada de las leyes fundamentales o políticas de una Nación, reglas que establecen la forma de gobierno concebida como las condiciones en que unos mandan y otros obedecen, no es novedad entre nosotros: Sus reglas principales habian estado en uso antiguamente; pero como no formaban un cuerpo, ni tenían afianzada su observancia, los interesados en quebrantarlas las habia hecho caer en olvido; las Córtes las hicieron revivir ${ }^{24}$. Sucede así en el caso de la Religión: la Constitución es un apoyo esencial de la misma porque todas sus reglas se dirigen á la mejora de las costumbres, y á la

${ }^{21} \mathrm{Cfr}$. Breve catecismo politico-español-constitucional, que a imitacion del de doctrina cristiana compuesto por el Señor Reynoso, presenta al publico E. D. D. E. A. Málaga, 1814, pp. 11-12. La Constitución es "admirable obra" (p. 10), "Código admirable" (p. 11), "libro bien meditado cuyos preceptos obligan a todos los españoles por razón de juramento" (p. 20), "sabia" (p. 22), dotada de un poder cuasi imperial (p. 24), y "digna de amor" (p. 28).

${ }^{22}$ Cfr. Breve catecismo politico-español-constitucional, ed. cit., p. 18.

${ }^{23}$ Cfr. M. López Cepero, Lecciones políticas para el uso de la juventud española por el Doctor Don Manuel Lopez Cepero Cura del Sagrario de Sevilla, $3^{\mathrm{a}}$ edición corregida por el autor, Madrid, 1814. Lecciones IX-XX, pp. 53 ss. En una línea análoga, cfr. D. de las Heras Ibarra, Catecismo natural del hombre libre, en donde se instruye a toda clase de personas acerca de su verdadero interes, derechos y deberes, Madrid, 1814, pp. 21-24.

${ }^{24}$ Cfr. D. J. Corradi, Catecismo politico, arreglado á la Constitucion de la Monarquia Española, para ilustracion del pueblo, instruccion de la juventud, y uso de las escuelas de primeras letras. Por D. J. Corradi, $2^{\text {a }}$ edición, Madrid, 1820 (con primeras ediciones en Palma y Madrid, 1812). Lección I, De la Constitucion, pp. 7-8. O, como añade en Lección V, Del Gobierno, p. 29, en todo país, para que haya orden y tranquilidad y los fuertes no atropellen a los débiles, debe haber quien por consentimiento de todos gobierne y disponga lo que juzgue conveniente al bien general: "La reglas, pues, con que estos han de gobernar y las condiciones con que los demás han de obedecer, son las que constituyen lo que se llama gobierno; y á estas reglas y condiciones se les da el nombre, como hemos visto, de leyes fundamentales de un país, y forman su Constitucion”. 
extirpación de los abusos, y á hacer que los españoles sean justos y benéficos ${ }^{25}$. El modelo ideal es el gobierno monárquico, derivado de esa Constitución, con unas Leyes Fundamentales que disciplinan los poderes separados e impiden el despotismo ya que actúan de frenos a la acción del poder ejecutivo. Eso fue lo que falló en el pasado y desembocó en tendencias despóticas entre nuestros gobernantes, ahora felizmente erradicadas: ¿Qué se entiende por Monárquico constitucional? El Monárquico justo, reglado por las leyes fundamentales, que como hemos dicho forman la Constitucion de un estado, y sin las cuales no seria gobierno monárquico, sino despótico ${ }^{26}$. Abundando en la cuestión religiosa y en el fundamento histórico último del texto, un anónimo párroco escribirá ya en tiempos del Trienio que la divisa de todo buen español es la Religión Católica, la Constitución, la Patria y el Rey, siendo la segunda la ley fundamental de la Monarquía española, dictada por los Padres de la Pátria, y publicada en Cádiz el año de 1812, cuyo principio esencial es el Misterio inefable de la Trinidad Santísima, compuesto de tres Personas distintas, Padre, Hijo y Espíritu Santo, y un solo Dios en Esencia, Autor y Supremo Legislador de la Sociedad. Esto impide que se contemplen cosas, ideas e indicaciones en la Constitución contrarias a la Religión e incluso que no se viertan en aquélla afirmaciones contrarias a las leyes patrias puesto que no hay en ella nada nuevo, algo que no se encuentre previamente en las leyes de España. La dotación del clero y un control de la libertad de imprenta permitirán a los españoles ser felices, constitucionales, justos y benéficos, siendo como es la Nación española muy moderada, circunspecta y religiosa ${ }^{27}$. A medio camino entre Religión y Leyes Fundamentales, los catecismos hacen una labor inmensa de educación constitucional puesto que permiten a todo el mundo acceder, de un modo simple y llano, a los antiguos arcanos del poder, a los contenidos mínimos de los derechos y de las libertades. Crean un lenguaje común, popular, con el cual explicar los entresijos de la Monarquía, siempre con esos dos tópicos presidiendo su labor.

En una línea más evolucionada y mejor construida, aparece la pléyade de autores que perciben la Constitución como lo que es a la luz de sus propias palabras y las de sus propios autores: una reconstrucción y aseguramiento de las viejas Leyes Fundamentales. Es el canon interpretativo historicista o histórico, no desconocido, como se ha visto, en lecturas previamente identificadas. El tono es superior al de los catecismos, puesto que sus destinatarios también son otros, y los argumentos vertidos tienen más solidez y enjundia. No debemos ver en estas voces deseo alguno de ocultación, mentira, falacia o camuflaje, sino concordancia con un universo intelectual del que estaban imbuidos los sujetos que viven a caballo entre el viejo y el nuevo orden político-jurídico,

\footnotetext{
${ }^{25}$ Cfr. D. J. Corradi, Catecismo político, ed. cit. Lección II, De la Nación española, pp. 13-14.

${ }^{26}$ Cfr. D. J. Corradi, Catecismo político, ed. cit. Lección V, Del Gobierno, pp. 33 y 37.

${ }^{27} \mathrm{Cfr}$. Catecismo historico, politico, religioso, y constitucional, que contiene en preguntas y respuestas, la explicacion sucinta de la Monarquia Española, promulgada en Cádiz á 19 de Marzo de 1812. Su autor un párroco español compatricio de la sin par Dulcinea, Madrid, 1822, pp. 1, 10-11 y 64-67.
} 
entre los dos siglos donde se decide el paso a la Edad contemporánea. Antes de la propia Constitución, muchos lo habían advertido así, indicando la presencia indiscutible de una Constitución histórica de raigambre gótica evolucionada en Castilla y Aragón de modo distinto (más republicanizada en el segundo de los casos), con poderes regios limitados y Cortes estamentales representando a la Nación y velando por la conducta de los monarcas, sobre todo, en cuestiones fiscales, Constitución que fue conculcada por la ignorancia y la ocultación, es decir, por el solo desconocimiento de sus contenidos y de sus depósitos ${ }^{28}$. Jovellanos sería el máximo exponente de esta línea de pensamiento, pero no llega a ver el nacimiento de la Constitución de Cádiz. Tras su aprobación en marzo de 1812, se sigue pensando lo mismo, dando un baño de antigüedad a los principios del liberalismo o, más bien, concibiendo el liberalismo no como novedad, sino con producto de factura histórica que ya existía en España desde hacía siglos. Hubo un pasado glorioso, plenamente liberal y con presencia de los elementos que lo singularizan (Cortes, poder limitado del rey, controles y garantías, derechos y libertades), pasado que se sitúa en el Medievo y al que se asocian el progreso en todos los campos, seguido de un proceso de degeneración, ocultación, desprecio e ignorancia de la Constitución, ahora felizmente recuperada y asentada, que se sitúa con la llegada de dinastías foráneas. Ha sido precisa esta sucesión de crisis para volver a las esencias constitucionales, para volver a la Edad Media, aunque mejorada y perfeccionada. Y lo es porque se debe evitar que en el futuro se vuelvan a producir tales depravaciones de una esencia política que es la que ha funcionado siempre y la que ha funcionado mejor. Lo hace así, por ejemplo, Canga Argüelles ${ }^{29}$, lo hacen los apasionados autores que rebaten a los redactores de $E l$ Conciso $^{30}$, el cura liberal José Antonio Posse desde tierras

\footnotetext{
${ }^{28}$ Por ejemplo, cfr. Fray M. Suárez de Santander, Carta de un religioso español, amante de su Patria, escrita á otro Religioso amigo suyo sobre la Constitucion del Reyno y abuso del poder (redactada en Toro en el año 1798, pero publicada por vez primera en Cádiz en 1808 y de nuevo aparecida en Madrid en 1814 y 1820, cultivando con abundancia los tópicos referidos), pp. 1-8; ¿Que es lo que mas importa a la España? Discurso de un miembro del populacho (sin fecha, ni lugar de edición, mas redactado en Teruel el 28 de junio de 1808), pp. 3-14; y M. J. Quintana, Carta de un representante de Aragon a sus comitentes, Palma de Mallorca, circa 1810, pp. 3-7.

${ }^{29}$ Cfr. J. Canga Argüelles, A todos los dependientes y empleados de los ramos de Hacienda del Exército $y$ Reyno de Valencia, y de las subdelegaciones de Alicante, Orihuela y Xijona, Con motivo del juramento á la Constitucion Politica de la Monarquia Española, Cádiz, 1812, pp. 2-6 (= también en el volumen Reflexiones sociales y otros escritos. Edición e introducción de Carmen García Monerris. Madrid, 2000, pp. 95-102): "Llegó el día en que el pueblo español renueva la carta respetable de sus derechos por cuya conservacion supieron dar su vida los Padillas y los Lanuzas; sufrieron los navarros y vizcaynos el odio de la tiranía, y el inmortal Barriolucio sufrió el encono envenenado del gabinete por haberlos sostenido con firmeza en las Córtes débiles del año de 1790 (...) Pero dexamos olvidar las antiguas leyes fundamentales de la Monarquia cuando desaparecio nuestra gloria y poder (...) La Constitucion política de la Monarquía, cerrando las puertas á la negra arbitrariedad, nos restituye á la elevacion de la cual nos derrocaron el olvido de nuestros derechos y la inobservancia pasiva de nuestras leyes, franqueándonos el camino de gloria que hollaron con planta osada los Cardonas y los Ruiz Diaz, los Toledos y los Bazanes”.

${ }^{30} \mathrm{Cfr}$. Explicacion legal y genuina de la nueva Constitucion á los editores del Conciso, que la agraviaron en su Periodico numero 19 en el día de su publicacion; cuyo articulo tiene la siguiente divisa: Dia de
} 
gallegas $^{31}$, algún religioso aislado ${ }^{32}$ y algún periodista minoritario ${ }^{33}$ o los abogados

San Josef "19 de marzo de 1812" "pág. 3", Madrid, 1812 (reimpresa en Santiago de Compostela ese mismo año), pp. 12-13 y 16: “¿A qué desacreditar nuestras antiguas leyes, sin en ellas se funda que han servido, y en gran parte sirven de modelo á las naciones mas cultas? (...) De esta igualdad, que es común á todos los hombres, desde el instante que nacen, es de la que hablan nuestras antiguas leyes, y ratifica sin variedad la Constitucion (...) Ni leyes ni Constitucion podrán obedecerse mientras no se respete á Dios y al público, y no haya sumision á las legítimas Potestades. Estos dos son los fundamentos de toda sociedad bien ordenada; pero uno y otro faltarán si ántes no se destierran los principios anárquico-revolucionarios de igualdad, irreligion, y libertad, tan opuestos á la naturaleza: á toda especie de gobiernos; y especialmente á la católica Monarquía española, que después de 17 siglos de explendor y grandeza, acaba la nacion de renovarla en el diez y nueve, jurando su Constitucion, y afirmándola con nuevas leyes". ${ }^{31}$ Cfr. J. A. Posse, Discurso sobre la Constitucion que dixo Don Juan Antonio Posse, Cura Párroco de San Andres, Diócesis de León, al publicarla á su pueblo en veinte y nueve de noviembre de mil ochocientos doce. Reimpreso á expensas de los redactores del Ciudadano por la Constitucion, La Coruña, 1813 (= citamos por Memorias del cura liberal don Juan Antonio Posse con su Discurso sobre la Constitución de 1812. Edición a cargo de Richard Herr, Madrid, 1984, pp. 251-274, especialmente, pp. 258, 264, 272-273 y 274): “12. Descendieron (los diputados gaditanos) hasta la raíz del gran árbol de la feudalidad, cuyas ramas llegaron á nosotros: y marchando entre abrojos y espinas, exâminaron los principios constitutivos de nuestra monarquía, la naturaleza de nuestro gobierno y el carácter de nuestra legislación: la idea que se debe tener de nuestras leyes fundamentales, de los intereses de todos los cuerpos y de los límites de sus pretensiones. Debaxo de las ruinas del coloso feudal sacaron los derechos de cada uno, y terminaron las disputas de los reyes y de la nacion, á fin de no ofrecer sino resultados ciertos y luminosos (...) 21. Nada habeis adquirido de nuevo: la ignorancia y la falta de energía de una parte y de la otra el poder y la arbitrariedad hicieron olvidar nuestros derechos y las leyes fundamentales de la nación: los hemos vuelto á recuperar en la mayor parte (...) 33. Tú [la ciudad de Cádiz] nos pegarás á la patria en que nacimos: de ti hemos recibido aquel noble orgullo, que se llama honor nacional, y aquella libertad razonable, que puede tenerse en una monarquía. Tú nos darás costumbres, disciplina severa, salud, órden, y una Constitución vigorosa en todos los ramos (...) 32. Gravad á su exemplo éste no menos estimable tesoro de nuestras leyes fundamentales en vuestros corazones (...) 36. La Constitución nos restituye todos estos derechos perdidos, y solo perjudica á los amantes del desórden y de la arbitrariedad".

${ }^{32}$ Cfr. M. Cortés y López, Exhortacion constitucional, que en 15 de agosto de 1813, pronunció en la Santa Iglesia Catedral de Segorbe el D. D. Miguel Cortés y López Canónigo Penitenciario Curado de la misma, Zaragoza, 1813, pp. 7-21, especialmente, p. 8. "Pero: ¿Será acaso alguna novedad que baxo el aspecto de libertad nos conduzca al libertinaje, á la anarquía ó á la irreligion? ¡Ah! Los amigos de Bonaparte bien quisieran desacreditar esta preciosa ley; los amantes de la arbitrariedad, de los desórdenes antiguos, los enemigos del mérito, y de la prosperidad nacional bien quisieran que el pueblo español la mirara como una novedad. Pero, ¿como lo conseguirán no siendo otra cosa que la antigua y sabia Constitucion de Aragon, mejorada con las leyes mas liberales y justas de las demas provincias de España? Bien quisieran que los pueblos sencillos la miraran con desconfianza: Pero ¿cómo lo lograrán siendo como es el compendio de la política mas sublime, de la religion mas pura y de la sabiduria mas profunda?".

${ }^{33}$ Cfr. J. M. Jecebek, El Fiscal Patriótico de España. Obra Periódica publicada los lunes y viernes de cada semana, Madrid, 1813, passim, especialmente, $\mathrm{n}^{\circ} 13$ (lunes, 22 de noviembre de 1813), p. 103: "Bien podemos decir sin temor de equivocarnos, que de todo quanto se ha dispuesto en nuestra época nada hay mas laudable, útil á la posteridad, y digno de inmortal memoria, que el reconocimiento del gobierno monarquico de España, en sus sucesiones, y el establecimiento de la Constitucion Nacional. Esta disposicion es tan arreglada al derecho natural, que hace compatibles (conforme él) los derechos de la corona, y la libertad del pueblo español, que según sus sábias leyes jamás debió ser gobernado por monarcas despóticos, y sí constitucionales; de forma que la declaracion en esta parte ha sido el rescate 


\section{mexicanos con especial fruición y apasionamiento ${ }^{34}$. No hay motivo para pensar en}

de la libertad nacional, y freno del despotismo que se había abrogado el trono"; nº 17 (lunes, 6 de diciembre de 1813), p. 136: "Huyamos pues de manchar nuestra opinion con una irracional é injusta diversidad de pareceres, que no es otra cosa que un espíritu de partido, destructor de nuestra existencia; y siguiendo como cuerdos nuestra acertada decision, lograremos los beneficios que de ella puede prometerse la patria, fundados en los sólidos cimientos de la Religion mas verdadera, del Rey mas virtuoso y amable, y de las leyes y constitucion mas benéficas y sábias" ; y n 19 (lunes, 13 de diciembre de 1813), pp. 146-152, donde se insiste en la "restauracion del gobierno monarquico constitucional" como fin de los escritos compilados, así como la defensa de la Religión y su conservación, y la destrucción del enemigo o enemigos opuestos a nuestra independencia "sin reconocer superioridad de ninguna nacion extranjera, ni someternos á sus auspicios ó decisiones, sobre lo qual tampoco hay mucho que discurrir".

${ }^{34} \mathrm{Cfr}$. Solemne acción de gracias que la Academia de Derecho español, público y privado de la capital de México da al Supremo Congreso de las Cortes Generales y Extraordinarias, por haber dictado la Constitución política de la Monarquía española. Celebrada el día 15 de marzo de 1813. En la Aula mayor del colegio más antiguo de San Pedro, San Pablo, y San Ildefonso, México, 1814, pp. 4-30, expuesta por Benito J. Guerra, abogado de las Audiencias de Guadalajara y México, sinodal y tesorero de su ilustre colegio, y fiscal de los cuerpos nacionales de artillería e ingenieros. Allí se habla de una "reforma general de sus constitucion politica para su mayor y mas acertado gobierno", y se indica con toda claridad lo que sigue, en pp. 10-11: "Penetrada de estos conocimientos la nacion española redujo á un código las leyes fundamentales, esparcidas antes en diversos cuerpos, aumentándolas ó mejorándolas en el modo que hoy admiramos en nuestra sábia Constitucion política. Ella nos trae las ventajas y bienes que disfrutan otras naciones cultas; y no podemos dexar de mirarla como el unico agente que dá impulso y fuerza á la nación misma, para conseguir toda su felicidad, ni dejaremos de conocer, que todo nuestro bien pende de la observancia de estas mismas leyes, y que con ellas será siempre la nacion lo que ha querido ser para su total engrandecimiento. Bien conoció que las mas de nuestras leyes, nuestras pragmáticas y autos acordados, estaban hechas en ocurrencias de casos particulares, y que solo fueron decisiones de algunos artículos casuales que en el dia se agitaban, exâminados civilmente con respecto á la materia que se discutía; pero sin relacion general, convinacion politica ni de estado, que abrazase, ó se encaminase á un punto fixo, y unido de legislacion fundamental, conciliado este en todas su partes por la universalidad de la jurisprudencia civil, política, gubernativa de derecho público, é interés general". Lo que se ha hecho, pues, es unir y unificar esas leyes dispersas, buscar una ligazón de las mismas para conseguir el "bien general apetecido", de resultas de lo cual aparece una Constitución admirable de la que se destacan las buenas cualidades de una legislación fundamental y en cuya exacta observancia se va a cimentar la opulencia de los ciudadanos, la riqueza del erario, "y el crédito, el lustre y la abundancia que constituyen la felidad (sic) pública de una nacion”. Sigue la arenga de réplica del licenciado Juan Francisco de Azcárate, pp. 31-40, con subsiguiente respuesta del licenciado Guerra, pp. 41-47, donde insiste más si cabe en la línea historicista previamente expuesta (especialmente, merecen destacarse las pp. 45-47: “(...) que fué convenir que se redujeran á efecto las leyes fundamentales del modo más proporcionado á las circunstancias (...) la Constitucion no ha hecho mas que reproducir todas las demás [leyes fundamentales] consecuentes á este principio [el de la soberanía nacional] (...) Las Córtes extraordinarias hicieron lo que el diestro arquitecto, que con los materiales del edificio destruido, lo repone, dandole otra perspectiva, que lo presenta como nuevo, sin serlo. En la Constitucion recopilaron todas las leyes que se hallaban esparcidas en diversos códigos, para que de esta suerte los ciudadanos tengan á la vista, y baxo del método mas claro, los derechos sagrados de la nacion, y los que los ligan con ella (...) que no habiendo las Córtes innovado las leyes fundamentales primitivas, sino unicamente aclarádolas, segun lo exigen las actuales circunstancias de los tiempos con los nobles fines explicados (...) Para que la ley se diga innovada, es necesario se altere su disposicion en lo principal. Si las leyes fundamentales antiguas, como supone el argumento, y es cierto, hicieron la felicidad nacional por la exac- 
falsedades, en tácticas aviesas o en subterfugios. No mintieron esos autores, ni los diputados gaditanos en sus intervenciones parlamentarias o en el resultado final de sus votaciones ${ }^{35}$. Creían firme y conscientemente en todo lo que decían. Hablaban de forma sincera y deliberada y en sus palabras hay un recurso constante: no se ha hecho una Constitución nueva, sino que se ha mejorado la antigua. El problema estribaba en determinar quién se tenía que ocupar de esas Leyes Fundamentales y en saber a ciencia cierta cuáles eran éstas, cuáles merecían tal calificativo de las múltiples que habitaban en el desván de la Historia, pero sin preguntarse por sujetos, instituciones y principios elementales, ya bastante decantados por el discurrir histórico, ya comúnmente aceptados, ya generalmente sabidos y admitidos por todos. Ahí estaba la clave de bóveda del debate. Quién y cuáles, pero con trasfondo pretérito indiscutible y asumido.

La Constitución tuvo así muchos lectores e intérpretes, prueba del carácter abierto que atesoraba, de su matriz histórica, dable a plurales comentarios y exégesis. Todo el mundo la leía, pero se leía de maneras diversas, opuestas, incluso contradictorias, con recorridos y conclusiones divergentes. Desde España y desde América. Desde Cádiz y desde otras partes del territorio nacional. Desde posturas realistas y desde posturas liberales. El texto era el mismo; los lectores no compartían esta igualdad de partida porque sus perspectivas diferían. De ahí, que fuese imposible contentar a todas las facciones y que todas presentasen $s u$ propio texto constitucional, adaptado a su credo respectivo. A ello ayudaba - ya se ha indicado a su debido momento- la inexistencia o insuficiencia de los dispositivos contemplados por el articulado constitucional para hacer factible la centralidad del texto gaditano, para generar una interpretación única y uniforme, de tipo general, de todos y cada uno de sus preceptos. Algo intentan hacer las Cortes en este sentido a través de las denuncias recibidas por infracciones constitucionales, pero infructuosamente: como no eran capaces de asegurar tal posición hegemónica, la situación se traducía en una confluencia de variadas periferias desde donde se glosaba e interpretaba la Constitución, sin que alguna de las visiones o lecturas tuviera marcada preponderancia sobre las otras. Sin embargo, había un cierto denominador común a todas las facciones: la idea de que subyacía a

titud con que se observaban, no innovandolas la Constitucion, y sí reproduciendo su tenor, con otras disposiciones muy utiles, todas harán la felicidad de la monarquía, si se cumplen con puntualidad en lo succesivo, y harán tambien la de los ciudadanos en particular". Hay una segunda arenga de licenciado Juan Gómez Navarrete, pp. 49-60, con segunda respuesta de menor enjundia, en pp. 61-70. Con carácter previo, Juan José Barberi, presidente de la Academia, introduce el discurso, pp. I-VII. Se dice que la Constitución organizó el gobierno bajo principios liberales, a la cual fue añadido todo lo conveniente para perfeccionarla "restituyéndose sus antiguos derechos, hollados por el despotismo, la ignorancia, la disolucion y la codicia". Las Cortes han inspirado confianza a los españoles, sosteniendo los primitivos derechos, salvándolos de las garras de la tiranía, "é hizo renacer la entereza con que nuestros abuelos se explicaban en las Cortes para promover y realizar el bien de la patria, por el que derramaron su sangre, y sacrificaron sus tesoros". La Nación ha recibido la Constitución política como un don concedido por el cielo para restituir al antiguo grado su mayor grandeza.

${ }^{35}$ Cfr. mi trabajo “Repensar la Constitución de 1812”, cit., pp. 94-110, para los debates parlamentarios. 
la Constitución escrita o formal una anciana Constitución histórica, tradicional o material, la cual se había plasmado por vez primera en un solo documento y se había ordenado de una forma más adecuada a la realidad de los tiempos. La Constitución se había encontrado, tras mucho tiempo desaparecida, y se había ordenado después de muchos siglos de dispersión y de caótica presentación. Había sido localizada y se había asentado su dominio sobre tierras hispánicas. Incluso los liberales también secundaron esa propuesta revitalizadora de las ancianas Leyes Fundamentales, como prueban los testimonios de J. M. Blanco White, del Conde de Toreno, de M. J. Quintana, J. Lorenzo Villanueva, Antonio Alcalá-Galiano ${ }^{36}$ y, sobre todo con una mayor contundencia y suficiente expresividad ya desde el mismo título de su obra, Agustín de Argüelles ${ }^{37}$. Todos ellos no hacen más que corroborar la idea profundamente sentida y sobradamente probada, a nuestro modesto entender, de que no se hizo nada nuevo en 1812, sino que se revisó el caudal constitucional que suministraba la Historia, es decir, se reconstruyó la Monarquía a partir de los elementos esenciales que la definían, ahora mejorados, perfeccionados y protegidos con nuevos instrumentos.

Años después, un periodista llamado Karl Marx afirmaría que la Constitución de 1812 no había sido más que la reproducción de los antiguos fueros, pero leídos a la luz de la Revolución Francesa y adaptados a las necesidades de la sociedad moderna, insistiendo en que las privaciones, restricciones o limitaciones al poder del rey, acaso lo aparentemente más novedoso del texto, a su juicio no eran otra cosa que disposiciones provenientes de los antiguos fueros de España, para concluir que tal texto constitucional era, ni más ni menos, que el resultado de un compromiso entre las ideas liberales del siglo XVIII y las oscuras tradiciones de la teocracia, y redondeaba la faena de esta forma:

Lejos de ser un copia servil de la Constitución francesa de 1791, fue un vástago genuino y original de la vida intelectual española, que regeneró las antiguas instituciones nacionales, que introdujo las medidas de reforma clamorosamente exigidas por los autores y estadistas más célebres del siglo XVIII, que hizo inevitables concesiones a los prejuicios populares $^{38}$.

\footnotetext{
${ }^{36}$ Cfr. mi trabajo "Repensar la Constitución de 1812”, cit., pp. 113-117, para las opiniones de los autores citados supra.

${ }^{37}$ Cfr. A. de Argüelles, Examen Histórico de la Reforma Constitucional de España, Estudio preliminar de Miguel Artola, Oviedo, 2002, tomo I, parte I, pp. 11 ss.; parte II, pp. 27 ss.; y tomo II, cap. VII, pp. 47 ss., especialmente, pp. 50-51. Publicada en el año 1835, no dejan de ser significativos los verbos que emplea Argüelles cuando se refiere al efecto causado por la Constitución: recobrar, proclamar de nuevo, reformar, volver a proclamar, restablecer, consagrar de nuevo, restaurar, síntoma de lo que uno de sus principales responsables pensaba del artificio constitucional cuando el paso del tiempo y las circunstancias le habían proporcionado otra perspectiva más serena y calmada para afrontar el examen de las labores gaditanas.

${ }^{38}$ Vid. P. Ribas (ed.), Karl Marx y Friedrich Engels. Escritos sobre España. Extractos de 1854, Madrid, 1998. España Revolucionaria [VI]. New York Daily Tribune, no 4.244, 24 de noviembre de 1854, pp. 136,137 y 139.
} 
Los ejemplos citados son buena prueba de lo dicho al principio de estas líneas: todo texto jurídico admite infinitas lecturas y todas, si se explican y justifican, son igualmente válidas, eficaces y defendibles. Todo texto, en suma, es relativo y no hay absolutos de ninguna clase. Pero las lecturas tienen que ir acompañadas de algo más que la mera exégesis textual, de algo más que la mera contemplación heurística del texto en cuestión: pretexto y contexto son igualmente indispensables para colocar en su justo término cada palabra, cada idea, cada concepto volcado en el texto jurídico de referencia. Sin ese encuadramiento, el resultado devendrá insuficiente y limitado. La Constitución de Cádiz, aquí compareciente para rendir merecido homenaje a un hombre bueno y sabio como es el Profesor J. A. Alejandre García, ha sido el laboratorio empleado para tales fines. Probablemente, lo mejor, lo más riguroso científicamente hablando, siga siendo leer la Constitución con las lentes de los hombres que la redactaron, esto es, leerla con las lentes y declamarla con las voces de todos aquellos que, en mayor o en menor medida, participaron en su propuesta, debate y redacción, y eludir así cualquier ínfula o derivación liberal, no presente más que de forma excepcional en tales tiempos. Cádiz fue, como ya hemos avanzado en estas y otras páginas anteriores, el testimonio final del siglo XVIII antes que el anticipo del nuevo mundo liberal. Si acudimos a los testimonios de los hombres que la forjaron, tanto dentro del Oratorio de San Felipe Neri como fuera de él, creando una incesante y fuerte opinión pública, no podemos concluir otra cosa más que aquélla que la propia Constitución indica en su arranque: las Cortes revisaron las Leyes Fundamentales de la Monarquía y las aseguraron con providencias, precauciones y dispositivos tendentes a evitar en el futuro crisis análogas a las que habían provocado ese proceso de resurrección, finalmente concluido, cuando la Monarquía a punto estuvo de fallecer por múltiples fallos y errores. La ignorancia, la ocultación, el secreto, los arcanos, vicios derivados todos ellos de la acción de los gobernantes (sobre todo, extranjeros, no nacionales; sobre todo, ministros, nunca monarcas), no debían volver a repetirse y el texto escrito jugaba a desempeñar ese papel en el futuro más inmediato. 